FEDERAL RESERVE BANK OF SAN FRANCISCO

WORKING PAPER SERIES

\title{
Global Price Dispersion: Are Prices Converging or Diverging?
}

\author{
Paul R. Bergin \\ University of California at Davis, and NBER \\ Reuven Glick \\ Federal Reserve Bank of San Francisco
}

December 2006

Working Paper 2006-50

http://www.frbsf.org/publications/economics/papers/2006/wp06-50bk.pdf

The views in this paper are solely the responsibility of the authors and should not be interpreted as reflecting the views of the Federal Reserve Bank of San Francisco or the Board of Governors of the Federal Reserve System. This paper was produced under the auspices of the Center for Pacific Basin Studies within the Economic Research Department of the Federal Reserve Bank of San Francisco. 


\title{
Global Price Dispersion: Are Prices Converging or Diverging?
}

\author{
Paul R. Bergin \\ Department of Economics, University of California at Davis, and NBER \\ Reuven Glick \\ Economic Research Department, Federal Reserve Bank of San Francisco
}

This draft: December 20, 2006

\begin{abstract}
:
This paper documents significant time-variation in the degree of global price convergence over the last two decades. In particular, there appears to be a general Ushaped pattern with price dispersion first falling and then rising in recent years, a pattern which is remarkably robust across country groupings and commodity groups. This timevariation is difficult to explain in terms of the standard gravity equation variables common in the literature, as these tend not to vary much over time or have not risen in recent years. However, regression analysis indicates that this time-varying pattern coincides well with oil price fluctuations, which are clearly time-varying and have risen substantially since the late 1990s. As a result, this paper offers new evidence on the role of transportation costs in driving international price dispersion.
\end{abstract}

\section{JEL classification: F4}

This paper was prepared for the Journal of International Money and Finance - Santa Cruz Center for International Economics Conference on "Financial and Commercial Integrations," held at the University of California at Santa Cruz on September 29-30, 2006. We thank Jim Lothian and other conference participants for helpful comments. We also thank Ann Lucas, Thien Nguyen, and Michael Simmons for research assistance. The views expressed below do not represent those of the Federal Reserve Bank of San Francisco or the Board of Governors of the Federal Reserve System.

P. Bergin / Department of Economics / University of California at Davis/ One Shields Ave. / Davis, CA 95616 USA prbergin@ucdavis.edu, ph (530) 752-8398, fax (530) 752-9382.

R. Glick / Economic Research Department / Federal Reserve Bank of San Francisco / 101 Market Street, San Francisco, CA 94105 USA reuven.glick@sf.frb.org, ph (415) 974-3184, fax (415) 9742168. 


\section{Introduction}

Evidence of rising global trade volume has encouraged the impression in the literature that world goods markets are becoming progressively more integrated. One might expect this integration also to be reflected in price data. In fact, price dispersion may be preferred as a metric of market integration, since it is the potential for arbitrage that determines price deviations between locations, not the actual amount of trade, which can be affected by many factors other than openness.

Indeed, numerous papers have studied the degree of international price dispersion, focusing on various issues. Crucini, Telmer, and Zachariades (2005) demonstrated the effect on price dispersion of basic gravity factors such as tradability and distance, usually interpreted to represent trade costs. Parsley and Wei (2002) examine the impact of currency arrangements, finding that country pairs with currency unions or other exchange rate stabilization have lower price dispersion.

The focus of this paper is on how dispersion varies in the time dimension. We begin with the observation that price convergence has been remarkably uneven over time. In particular, if one looks at the usual mean square error measures of price dispersion, a trend of convergence from 1990 through 1997 appears to be interrupted and reversed in subsequent years, up to the end of our data set in 2005. The data appear to imply a general U-shaped pattern over the last one and a half decades. Engel and Rogers (2004) and Bergin and Glick (2005) observed such a pattern for a set of European countries. We find here that this pattern also applies more broadly. The decline in price dispersion in the first part of the sample is consistent with the view that the world has become increasingly more trade integrated over time, due to declining government barriers and declining costs to transportation and communication. More surprising and requiring explanation is why price dispersion has increased in more recent years.

This U-shaped pattern in price dispersion over time applies to varying degrees over various subsets of our data sample, including the full set of 70 countries, city pairs within developing countries as well as pairs within developed countries, and even cities within the U.S. alone. The pattern also applies to varying degrees over eight different classifications of commodities, including food, clothing and footwear, and household supplies. While variation in the degree of rising price dispersion indicates that different factors might be at work in different sets of cities, or that factors might affect city pairs differently, the fact that a noticeable U-shaped pattern is present in all cuts of the data indicate some common factor is also at work. 
This observation motivates an investigation of time-varying features of the data series known from past work to be related to price convergence. Examining the usual set of regressors from past work, few are time varying and none varies in a way that corresponds with the Ushaped pattern in price dispersion. We further check if the nature of the relationships between these regressors and price dispersion has shifted over time. For example, while exchange rate volatility has not risen over time, the effect it has on price dispersion potentially might have increased, due the fact that exchange rate pass-through appears to have decreased over time. Our panel data set is amenable to testing such a hypothesis. Most of the regression coefficients evidence no significant time variation; among those that do, none varies in a way helpful in explaining the U-shaped patter noted above, with the exception of distance. This suggests that some common factor affecting the cost of transporting goods a given distance may be at work.

Pursuing this possibility, we search for additional regressors that are time-varying which might contribute to time-varying price dispersion. Of special interest are the price of oil and indexes of transportation costs, which relate directly to existing theories underlying gravity regressions and price wedges (see Anderson and van Wincoop 2004, Corsetti and Dedola 2005). But to our knowledge, no one previously has included these series directly in price dispersion regressions. While distance may be a useful proxy for capturing broadly the effects of transportation costs, this clearly is not a time-varying variable that can help explain our observation. In contrast, no one is likely to miss the fact that the price of oil is highly time varying. Indeed, we do find that these transportation cost variables vary in a way coinciding with price dispersion, with a noted rise in costs after 1997 when price dispersion was on the rise.

These observations are documented using panel regressions on an Economist Intelligence Unit data set of 101 tradable goods in 108 cities in 70 countries, for the years 1990 to 2005. Year fixed effects are included to control for unobserved time-series variation, and used to document the U-shaped pattern in price dispersion. We further document the U-shaped pattern by including time trends for the pre 1997 and post 1997 periods. A range of explanatory variables are progressively added to the panel regression to search for contributors to the time-varying pattern of price dispersion that we observe.

One contribution of this paper is that it offers a new stylized fact about price dispersion, which invites study and a more complete explanation in future research. A second contribution is that it also offers suggestive new evidence on the role of oil-related transportation costs as an important driver of international price dispersion. 
II. Data

In our analysis we use data on actual price levels, not price indexes. The data are obtained from the Worldwide Cost of Living Survey conducted by the Economist Intelligence Unit (EIU), which records local prices for over 160 individual goods and services in more than 120 cities worldwide. ${ }^{1}$ The goods are narrowly defined, e.g. apples (1 kg), men’s raincoat (Burberry type), and light bulbs (2, 60 watt). For many goods in the survey, prices are sampled separately from two different outlets, a "high-price” and "low-price” outlet. For example, food and beverage prices are sampled from supermarkets and convenience stores. We use prices from the supermarket type outlets, which are likely to be more comparable across cities. The data set also includes many service items such as telephone and line, moderate hotel (single room), and man's haircut, which would most naturally be classified as non-tradable. The data are available annually from 1990 to 2005. All prices are recorded in local currency and converted into dollars.

The EIU database does not contain a price quote for all goods and cities in every year.

Since we are interested in both cross-sectional and time series variation, we assembled data for the same set of products for cities where generally less than $30 \%$ of the observations were missing in any given year. We use the same set of 101 tradable goods as used by Engel and Rogers in their study of price dispersion in Europe. ${ }^{2}$ The cities in our sample consist of the 83 cities in 70 countries (14 of these cities are in the United States) in the analysis of Parsley and Wei (2002), augmented to include an additional 25 cities in these countries that Parsley and Wei excluded. ${ }^{3}$ Thus our panel consists of price data on 101 tradable products in 108 cities in 70 countries. ${ }^{4}$ Appendix Tables 1 and 2 list the goods and cities included. For comparison we also assembled price data for a set of 30 nontraded items and services. ${ }^{5}$

\footnotetext{
${ }^{1}$ The EIU survey is used to calculate cost-of-living indexes for multinational corporations with employees located around the world. The data set is described in more detail at http://eiu.enumerate.com/asp/wcol_HelpAboutEIU.

${ }^{2}$ Engel and Rogers (2004) included only goods for which a price is recorded in every year for at least 15 of the 18 European cities in their analysis.

${ }^{3}$ Aside from the United States, Parsley and Wei (2002) include only 1 city per country in their sample. Our dataset contains 16 countries where data is available for multiple cities: the U.S. with 14, Australia and Germany with 5, Canada with 4, China and Saudi Arabia with 3, and Brazil, France, India, Italy, Japan, New Zealand, Russia, Spain, Switzerland, and the United Arab Emirates each with 2. The sample is not fully balanced as some cities are missing data for all goods in some years: cities missing data in 1990 included Douala, Guangzhou, Honolulu, Kuwait, Libreville, Lima, Shanghai, and St. Petersburg; in 1991, Guangzhou, Honolulu, Shanghai, and St. Petersburg; in 1992, Guangzhou, Shanghai, and St. Petersburg; in 1993 and 1994, St. Petersburg; in 2002, Port Moresby; in 2003, Libreville; in 2004, Libreville; and in 2005, Casablanca and Dakar. In our robustness analysis we check the sensitivity of results to (i) using a fully balanced panel by excluding all cities without price data for all years 1990 to 2005 and (ii) to eliminating city pairs in the same country and constraining the sample to one city per country. ${ }^{4}$ The dataset used by Parsley and Wei (2002) contains 95 traded goods. Their set is virtually identical to that of Engel and Rogers (2004), with the difference that Parsley and Wei include yogurt, cigarettes (local brand), cigarettes (Marlboro), tennis balls, and fast food snacks, but exclude butter, veal chops, veal fillet,
} 


\section{Measuring Price Dispersion}

We compare price level differences across cities in different countries in order to answer whether increased trade and global integration of goods markets has been accompanied by declining price dispersion. We define price dispersion across cities as the mean squared error (MSE) of relative (logs of) prices. More specifically, let $P_{i, t}^{k}$, be the price of good $k$ in city $i$ at time $t$, where all prices are expressed in dollars. For a given city pair $(i, j)$, the relative price difference for a given good $k$ at time $t$ in percentage terms (where lower case denotes logs) is :

$$
q_{i j, t}^{k}=p_{i, t}^{k}-p_{j, t}^{k}
$$

We define the average price dispersion at time $t$ for the city pair $(i, j)$ as the mean square error of $q_{i j, t}^{k}$ across all products $k$

$$
M S E_{i j, t}=\sum_{k \in K}\left(q_{i j, t}^{k}\right)^{2} / K_{T}
$$

where $K$ is the set of products and $K_{T}$ is the total number of products ( =101 if product prices are available for all goods in both cities). ${ }^{6}$

There are potentially 5778 city pairs $(=(108 \times 107) / 2)$ - each with up to 16 yearly observations. Thus, the sample consists of a maximum of 92,448 ( = 5778x16) observations of price dispersion among city pairs for 101 goods.

Figure 1 presents the time series of our measure of price dispersion averaged over all city-pairs on a year-by-year basis over the period 1990 to 2005, i.e.

$$
M S E_{i \bar{j}, t}=\sum_{i j \in C} M S E_{i j, t} / C_{T}=\sum_{i j \in C}\left(\sum_{k \in K}\left(q_{i j, t}^{k}\right)^{2} / K\right) / C_{T}
$$

veal roast, women's raincoat, girl's dress, compact disc, color television, international weekly newsmagazine, paperback novel, and electric toaster. Other papers using EIU data include Crucini, Telmer, and Zachariades (2003), Engel, Rogers, and Wang (2003), and Crucini and Shintani (2006). ${ }^{5}$ This set consists of 30 items -- the 37 items used by Engel and Rogers (2004) less car insurance and apartment and housing costs which were not available for a significant proportion of the cities in our sample.

${ }^{6}$ Parsley and Wei (2002) measure price dispersion by the standard deviation of the distribution of the percentage price dispersion, over their 95 products. To control for the possibility that the magnitude of the deviation from the law-of-one-price may depend on the type of product, they remove the mean of the price gap for each good across all city pairs:

$$
M S E_{i j, t}^{\prime}=\sum_{k \in K}\left(q_{i j, t}^{k}-q_{i j, t}^{k}\right)^{2} / K \text {, where } q_{i j, t}^{k} \equiv \sum_{i j \in \mathrm{C}} q_{i j, t}^{k} / C_{T}
$$

and $C_{T}$ equals the number of city pairs. They also consider two alternative ways measures of dispersion -the inter-quartile range, i.e. the difference between the 75th and 25th quartiles in the distribution of $q_{i j, t}^{k}-q_{i j, t}^{k}$, and the standard deviation of the absolute percentage price differences $\left|q_{i j, t}^{k}-q_{i j, t}^{k}\right|$ over the 95 products for a given city-pair and time period. In our robustness analysis we report results with alternative measures of price dispersion, including the "demeaned" variant of the mean square error above. 
where $C$ is the set of city pairs $i j=1 \ldots C_{T}$ (in year $t$ ). A rough U-shaped pattern is apparent in this figure, with dispersion falling from 1990 to 1997 and then gradually rising through 2005. Figure 1 also shows that the pattern is little affected if we exclude city pairs within the same country. ${ }^{7}$ The fact that this line is somewhat higher implies that price dispersion is less among cities within the same borders. ${ }^{8} 9$

The U pattern applies broadly across various subgroupings of countries. Figure 2 disaggregates the data by distinguishing between industrial and developing countries. It plots average price dispersion for city pairs where (a) both are in industrial countries, i.e. intraindustrial country city pairs, (b) both are in developing countries, i.e. intra-developing country city pairs, and (c) only one city is in an industrial country, while the other is in a developing country. ${ }^{10}$ Again, the U-shaped time profile is observable in all cases, with the profile more pronounced when one or both cities are in a developing country. Observe also that price dispersion is lower among industrial countries than among developing countries, suggesting more trade integration by this metric. Figure 3 displays the cases of eurozone city pairs, U.S. city pairs alone, and East Asian city pairs including Japan, all of which show a similar pattern of variation over time, though with different degrees of "U-ness."11

Figure 4 shows that the U-pattern is present also for various disaggregations of the data into commodity groups; price dispersion among a set of nontraded goods and services is also plotted for comparison. There are clear differences between commodity groups in terms of average levels of price dispersion, with high dispersion among perishable food items and nontraded goods, and low dispersion among household supplies and recreation. Nonetheless, the U-shaped pattern over time is consistent across almost all of the commodity groups, with falling levels of dispersion until 1997 and rising dispersion afterward.

Table 1 reports tests of the statistical significance of the U-shaped pattern. The first column of Table 1 reports the mean (across traded goods) of the difference in MSE for three periods: 1990-1997, 1997-2005 and the full sample 1990-2005. These are reported as the

\footnotetext{
${ }^{7}$ Using a sample of city pairs with only one city per country (aside from the U.S.) and a somewhat different price dispersion measure based on EIU price data, Parsley and Wei (2002) also find price dispersion declines through 1997, but only rises slightly through 2000 when their sample period ends. ${ }^{8}$ Lothian (2001) notes that measures of integration in financial markets also show time variation and occasional reversals. However, these cases tend to coincide with major political and economic disruptions. Lothian (2006) observes a U-shaped pattern in real interest rate dispersion in Latin America, but finds no such pattern for other regions.

${ }^{9}$ The rise in price dispersion in the latter half of the sample may be especially surprising, given the rise of internet usage and other factors at this time enhancing price transparency across locations.

${ }^{10}$ The set of industrial countries includes countries in Western Europe, Austria, the United States, Canada, Australia, New Zealand, and Japan.

${ }^{11}$ The East Asia cities include Tokyo, Osaka, Bangkok, Beijing, Hong Kong, Jakarta, Kuala Lumpur, Manila, Singapore, Taipei, Guangzhou (from 1993 on), and Shanghai (from 1993 on).
} 
difference between the later MSE and the initial MSE (as in Figure 1) so that a positive number represents an increase in dispersion. For example, the first row deals with the full sample, where for each of the 101 goods categories we compute MSE measures of price dispersion across all country pairs. The table reports the mean value of the change in price dispersion, averaged over the 101 goods categories as well the standard deviation of this measure over the 101 goods. The table reports that the MSE for the full sample declined over the subperiod, 1990-1997, and rose over the period, 1997-2005, confirming the U-shaped pattern in Figure 1. The decline over the early period was greater than the later period, so the mean price dispersion fell over the whole sample period. All of these changes are statistically significant at the $1 \%$ level. Table 1 also looks at the change of price dispersion for regional subsamples and for product categories of goods within our data, confirming the observations from the figures discussed above.

\section{Regression Analysis}

\section{Specification}

We now turn to empirical analysis of possible explanations for the price dispersion in our sample. For empirical purposes, we model price dispersion between any two cities as a function of trade friction determinants, including the log distance between them, the existence of common language, adjacent national borders, tariff barriers, a dummy for cities in the same country, institutional arrangement variables, including membership in regional trade agreements or currency unions, and measures of exchange rate variability:

$$
\begin{aligned}
\text { MSE }_{i j, t}= & \alpha_{0}+\alpha_{l} \ln (\text { Distance })_{i j}+\alpha_{2} \text { Border }_{i j}+\alpha_{3} \text { ComLang }_{i j}+\alpha_{4} \operatorname{Tariff}_{i j, t} \\
& +\alpha_{5} \text { SameCountry }_{i j}+\alpha_{6} \mathrm{RTA}_{i j, t}+\alpha_{7} \operatorname{CurU}_{i j, t}+\alpha_{8} \text { CurCrisis }_{i j, t}+\alpha_{9} \operatorname{XRVol}_{i j, t} \\
& +\sum_{i} \beta_{i} \operatorname{City}_{i}+\sum_{j} \beta_{j} \operatorname{City}_{j}+\sum_{t=1991}^{2005} \lambda_{t} \mathrm{Y}_{t}+\varepsilon_{i j, t}
\end{aligned}
$$

where $i$ and $j$ denote cities, $t$ denotes time, and the variables are defined as:

- $\operatorname{MSE}_{i j, t}$ is the measure of price dispersion between cities $i$ and $j$

- $\quad$ Distance $_{i t}$ is the (great circle) distance between the cities $i$ and $j$

- $\quad$ ComLang $_{i j}$ is a binary variable which is unity if $i$ and $j$ have a common language

- $\quad$ Border $_{i j}$ is a binary variable which is unity if $i$ and $j$ are in different countries sharing a land border

- $\quad$ Tariff $_{i j, t}$ is the sum of the average tariff rates of the countries in which cities $i$ and $j$ are located, unless the two cities are in the same country (e.g. the United States) or free trade area (e.g. the European Union) in which case it is set equal to zero

- SameCountry ${ }_{i j}$ is a binary variable which is unity if both cities are located within the same country 
- RTA $_{i j, t}$ is a binary variable which is unity if $i$ and $j$ are in different countries participating in a regional trade agreement

- $\quad \operatorname{CurU}_{i j, t}$ is a binary variable which is unity if $i$ and $j$ are different countries engaged in a currency union

- $\quad$ CurCrisis $_{i j, t}$ is a binary variable if either $i$ or $j$ was involved in a currency crisis at time

- $\mathrm{XRVol}_{i j, t}$ is a measure of volatility of bilateral nominal exchange rates (between the countries of city-pair involved) during the year

- $\quad$ City $_{i}$ and $\mathrm{Y}_{t}$ are city and year dummy variables

- $\alpha_{i}, \beta_{i}, \lambda_{i}$ are coefficients; and

- $\varepsilon_{i j, t}$ represents other influences on price dispersion, assumed to be well behaved.

Note that the regression includes city fixed effects and year fixed effects to capture factors that may affect the dispersion in prices between cities that are not otherwise in the list of regressors.

The CIA's World Factbook is used to provide a number of country-specific variables, including land area, physically contiguous neighbors, and language. ${ }^{12}$ Distance is calculated with the great circle formula using each city's latitude and longitude data obtained from assorted websites. ${ }^{13}$

We use data on the simple mean tariff rates from the World Bank's World Development Indicators (WDI) for the years 1999 through 2005. For each country in a particular WDI issue, aggregate tariff levels are usually provided for two years, typically in the early 1990s and in a more recent year. The multiple issues of the WDI provide tariff data for multiple (i.e. more than two) years for most countries. We assume that the tariff level for 1990 is equal to the level for the earliest reported year and adjust the tariff rate down (or up) in subsequent years using the next reported figures. ${ }^{14}$ Our bilateral tariff measure is constructed as the simple sum of the aggregate tariff rate levels of both countries.

We define the currency union variable using the "loose” measure constructed by Glick and Rose (2002), defined as country pairs using a common currency or with hard pegs for an extended period of time. ${ }^{15}$

\footnotetext{
${ }^{12}$ The website is: http://www.odci.gov/cia/publications/factbook.

${ }^{13}$ These included http://www.mapsofworld.com/lat_long/ and http:// www.infoplease.com/ipa/A0001769.html.

${ }^{14}$ Tariff rates for Bahrain and the United Arab Emirates were drawn from country reports on the WTO and IMF websites.

${ }^{15}$ The benchmark definition of currency unions used by Glick and Rose (2002) includes only pairs with common currencies or hard pegs at 1:1 or 2:1 rates. Hard fixes at other rates (such as those of Hong Kong, Estonia, or Denmark) are not treated as currency unions under this definition. Their "loose" measure includes the latter arrangements. Note that definition assumes "transitivity", i.e. if countries a and b are each in a union with $\mathrm{c}$, then $\mathrm{a}$ and $\mathrm{b}$ are in a union with each other.
} 
The regional trade union variable includes city pairs in countries involved in the European Union (EU), European Free Trade Association (EFTA), Central European Free Trade Association, North American Free Trade Area (NAFTA), Mercado Común del Sur (Mercosur), Central American Common Market (CACM), Andean Community Nations (CAN), Asean Free Trade Area (AFTA), South Asian Preferential Trade Agreement (SAPTA), Australia-New Zealand Closer Economic Relations Pact (ANZCERTA), Papua New Guinea- Australia Trade and Commercial Relation Agreement (PATCRA), or the U.S.-Israel Free Trade Area.

The crisis variable indicator is drawn from Glick and Hutchison (2006), who identify currency crises as "large" changes in a monthly index of currency pressure, measured as a weighted average of monthly real exchange rate changes and monthly (percent) reserve losses; these data are updated through 2005. Exchange rate variability is defined as the standard deviation of changes in the monthly bilateral exchange rate (between the countries of the citypairs involved) during each year.

\section{Benchmark Regression Results}

We begin by estimating our gravity equation using a city fixed-effect panel OLS estimator with a full set of year-specific intercepts included. Standard errors are clustered at the city-pair level to address potential problems of heteroskedasticity and autocorrelation in the error terms. $^{16}$

Table 2 presents the benchmark regression results for the full world data set. Column 1 shows a regression of price dispersion on the usual gravity equation model variables, that is, the variables that have been explored in previous research (e.g. Engel, Rogers, and Wang, 2003; Crucini, Telmer and Zachariadis, 2003). The coefficients on these all have the expected signs. Price dispersion increases with distance and tariffs, and it decreases with a shared border, common language, or when located within the same country. ${ }^{17}$ In addition, price dispersion declines when countries participate in a regional trade agreement or in a currency union. ${ }^{18}$ The coefficients for the year dummies are not reported in the table, but are plotted instead below the table in panel (1). The U-shaped pattern is evident in these year dummies, indicating that this

\footnotetext{
${ }^{16}$ All estimation is done with STATA 9.0. Clustering at the country pair level allows the variance to differ across pairs and permits an unstructured covariance within the clusters to control for correlation across time.

${ }^{17}$ Note that the language variable is defined to include cities with residents speaking a common language in the same country as well as in different countries.

${ }^{18}$ Parsley and Wei (2002) find that their basic results survive unaffected even after endogenizing the formation of common unions. It is also possible for us to test separately for possible heterogeneity in the effects on price dispersion of participation of specific monetary unions, such as the U.S., Eurozone, or CFA.)
} 
stylized fact is not attributable to the "usual suspect" variables studied in past research. Confidence bands are also reported in the figure based upon the standard errors from the regression. Although 16 years of annual data provide much less information regarding time dimension than in the cross-sectional dimension, the confidence bands indicate that the U-shaped pattern in the time-dimension is statistically significant, both for the years until 1997 when dispersion is falling and the subsequent years when dispersion rose.

A useful means of documenting and measuring the U-shape is shown in column 2 of Table 2, where we include two time trends in place of the individual year dummies, one running from 1990 to 1997, and the other from 1997 to $2005 .{ }^{19}$ Both time trends are statistically significant, with the first one negative and the second positive. We will use these pair of coefficients as a metric of the degree of U-shape in subsequent regressions. Lower coefficient values characterize a "shallower" degree of "U-ness," while the extent to which the coefficient for the 1997-2005 trend is smaller than that for 1990-1997 reflects the degree of asymmetry in the magnitudes of the earlier decline and subsequent increase in price dispersion.

Given that the usual suspects tend not to vary much over time, it may not be surprising that they cannot account for the time-varying nature of price dispersion over our sample. We now consider other possible contributors to price dispersion that are more likely to vary over time. One possibility is exchange rate variability. Column 3 of Table 2 reports results for a regression adding in the volatility of bilateral exchange rates as well as the occurrence of a currency crisis in a given year. ${ }^{20}$ The results indicate that greater price dispersion is associated with greater nominal exchange rate variability and with the occurrence of a currency crisis. ${ }^{21}$ However, these regressors account for little of the U-shaped time variation in price dispersion. The time dummies for the regression, reported in panel (3) below Table 2, still contain the U-shape, and when the pair of trends are included in the regression to measure the degree of U-shape, the coefficients in column 4 of the table show they remain strongly significant.

To explore how sensitive are our results to the country sample, Table 3 reports results for (a) intra industrial country city pairs, (b) intra developing country pairs, and (c) industrialdeveloping country city pairs. In the latter two country groupings, the U-shape time pattern in price dispersion is very pronounced; in the case of the industrial country city pairs, a shallow U-

\footnotetext{
${ }^{19}$ Specifically, the trend 1990-1997 variable has values -7 in 1990, -6 in 1991, .., 0 in 1997 and all subsequent years, while the trend 1997-2005 variable has values 0 in 1990 through 1997, 1 in 1998, 2 in 1999, etc.

${ }^{20}$ To the extent that there are timing differences in the collection of goods price data across country pairs, the exchange rate variability variables may also reflect measurement error.

${ }^{21}$ There may well be lagged effects on price dispersion of some of these variables, such as currency crises. This suggests the application of more dynamic panel estimation methods.
} 
shape pattern is discernible through $2000 .^{22}$ (Note the vertical scale in the year dummy plots vary over the regressions in Table 3.)

Table 4 reports results for city pairs in Eurozone countries, the United States, and East Asia (including Japan). Consistent with the finding for the set of cities in industrial countries overall, the year effects display a shallow U-shape pattern for Eurozone and U.S. region cities. ${ }^{23}$ The same is true for city pairs in the region of East Asia. ${ }^{24}$

\section{Possible Explanations of “U-ness” in Price Dispersion}

Greater international economic integration may well have lead to lower price dispersion in the first part of our sample. But what explains the increase in price dispersion in more recent years?

Examining the two exchange-rate related regressors indicates that neither is time varying in a manner that is helpful in explaining the pattern in price dispersion. Figures $5 \mathrm{a}$ and $5 \mathrm{~b}$ plot the yearly means of exchange rate volatility and the occurrence of currency crises across the pairs in the sample. These variables take on large values in several points during our sample period, but no U-shape is evident. The figures also report results when the sample is reduced to include only one city per country. This eliminates same-country city pairs (as well as multiple city pairs for any two countries) without any exchange rate variability and raises the average exchange rate volatility and the frequency of currency crises.

Another possibility is that the systematic response of the economies to these variables is time varying. For example, there is some evidence that the pass-through of exchange rate movements to import prices has fallen over time. This potentially could make price dispersion more responsive to episodes of exchange rate variability during the latter part of our sample where price dispersion turns upward. To investigate this possibility, a panel regression is estimated that interacts the exchange rate volatility variable with our set of individual year dummies over the period 1991 to 2005. The resulting estimates for the coefficient for each year

\footnotetext{
${ }^{22}$ Note that currency unions have a significantly positive effect on price dispersion for industrial countries. This reflects apparently higher price dispersion among Eurozone countries after 1999 compared to other city pairs, including city pairs in the United States, city pairs within individual European countries. When the sample is limited to including only one city per country, the currency union variable is no longer significant.

${ }^{23}$ Engel and Rogers (2004) also find declining price dispersion within the Eurozone during most of the 1990s, a trend they attribute to implementation of the Single European Market program. They also detect a rise in price dispersion in the region in the latter part of their sample, a change they do not seek to explain. Bergin and Glick (2005), with a longer sample period, find this pattern as well.

${ }^{24}$ Note that currency unions have a positive and significant effect on price dispersion for East Asia. This reflects the coding of Malaysia and Hong Kong as being in a currency union beginning in 1998 when the former pegged to the dollar. Evidently other factors associated with the Asia currency crisis and not controlled for in the regression increased price dispersion among these countries.
} 
are plotted with their confidence intervals in Figure 6a. This figure shows that there was statistically significant variation over time in the sensitivity of price dispersion to exchange rate volatility. However, there does not appear much correspondence of this time variation with the Ushaped pattern in price dispersion through 2002, as the coefficient tended to move through several cycles of rises and declines during this period. Only since 2002 does there appear to be a sharp increase in the degree of sensitivity to exchange rate volatility. Further investigation is warranted.

Figure $6 \mathrm{~b}$ reports the results for a similar exercise for variation in the sensitivity of price dispersion to distance. Here a rough U-shape is apparent, with the sensitivity to distance first declining and then rising. This suggests that some common factor affecting the cost of transporting goods a given distance may be at work.

An obvious candidate is the price of oil, which has varied significantly over time. This is a logical candidate, given that price dispersion results in part from the transportation costs that impose a wedge in price setting. If oil prices raise transportation costs, they should increase the size of the price wedge for imported goods, raising average price dispersion. In addition, it should raise costs proportionately more for countries further apart. Hummels (1999b, 2001) documents the importance of transportation costs, finding that they may account for over 25 percent of an imported good's cost. ${ }^{25}$

In fact, a plot of (real) oil prices in Figure 7 shows that it is time-varying in a manner that roughly coincides with the pattern in price dispersion, in that the real price of oil reached a low point in the sample shortly after 1997 and rose gradually in subsequent years. ${ }^{26}$ For comparison, the figure also plots measures of U.S. air and freight transport costs, which also rose at the end of the sample. ${ }^{27}$

In the absence of a general measure of world transport costs, we use oil prices to proxy for trends in such costs. ${ }^{28}$ Table 5 , column 1 reports the result of including in the regression the

\footnotetext{
${ }^{25}$ Transportation costs will matter less for some goods than others, such as nontradeds or locally produced tradable goods. The fact that price dispersion is U-shaped also among goods classified as nontraded is not evidence against an explanation based on transportation costs. Even final goods that are nontraded usually require inputs that are traded or at least require transport from other locations. So transportation costs can affect their marginal costs and hence prices.

${ }^{26}$ The real price of oil is calculated by deflating nominal crude oil spot price data from the OECD 2006 Factbook by the U.S. CPI index.

${ }^{27}$ The transport cost series used are international transportion price indexes for U.S. imports obtained from the BLS website at http://www.bls.gov/pub/suppl/ximpim.srv1.txt. The plotted series in Figure 7 are deflated by the U.S. CPI index.

${ }^{28}$ Hummels (1999a) presents data on global transport costs since World War II, but these data only extend to 1996. We also note that, in addition to fuel costs, transport costs depend on operating costs (e.g. labor wages), capital costs of shipping equipment (e.g. ships, railroad cars, trucks, and airplanes), and new technology (e.g. container use). We abstract from these considerations.
} 
log of the real price of oil, without year effects, for our world sample. This variable is highly significant, associated with a positive effect on price dispersion. Due to multicollinearity between the oil-price time series with the year dummies, the time dummies were not included in the regression above. But we do subsequently regress the residuals of the regression on year dummies as a gauge of their remaining variation over time. The coefficient estimates on year dummies are plotted below the regression results in Table 5. These no longer display a U-shape, so it appears that the time-series on the price of oil is an effective way of capturing the U-shape variation in price dispersion over time, particularly the upward slope in more recent years. ${ }^{29}$ We also report the results of regressing the residuals of this regression on the time trends for 1990-1997 and 1997-2005. These variables though smaller in magnitude, are still significant, indicating that though the oil variable captures some of the recent increase in price dispersion, it does not catch all of it.

To gauge visually how much oil prices explain, Figure 8 plots MSE for the world sample (the same series presented in Figure 1) together with a measure of MSE adjusted for the effects of oil prices. ${ }^{30}$ The figure shows that while oil price did not contribute to the fall in price dispersion in the first half of the sample, it does account in the regression for the other portion of the Ushape, the upward trend in the second half of the sample. Once the oil price effect is subtracted out, the remaining MSE fluctuations no longer have a noticeable upward trend after 1997.

The explanation above in terms of oil prices that works so well for the full world sample generally applies well for city pairs involving developing countries, but not for the industrial country subgrouping. Columns 2, 3, and 4 in Table 5 report results for (a) intra industrial country city pairs, (b) intra developing country pairs, and (c) industrial-developing country city pairs. In the case of the latter two subgroupings, the introduction of the oil price variable captures much of the U-shape in the post-1997 period. In the case of industrial country city pairs, the oil price though significant, is small in magnitude and does not reduce the U-shape; some other factor must be at work generating the U-shaped time profile of price dispersion in this case. See Bergin and Glick (2005) for a possible explanation. ${ }^{31}$

To investigate further the channel through with oil price is working, the fifth column of table 5 shows results from a regression that interacts the price of oil with distance. Does oil price

\footnotetext{
${ }^{29}$ We do not take account of how higher oil prices may affect production costs as well as transport costs.

${ }^{30}$ Specifically, we subtract from MSE the estimated coefficient of oil prices in Table 5, column 1 (0.127) times the difference between the log of oil prices each year and its sample mean.

${ }^{31}$ Bergin and Glick's (2005) argument rests on the view that much trade integration takes the form of reductions in fixed, rather than variable, costs of trade and that variable trade costs are heterogenous across goods. In this case, greater integration may allow entry of previously costly to transport goods that increases cross-country price dispersion.
} 
work through a story based on transportation costs? This interaction variable is informative on this point, in that it includes the variation in the time dimension of the oil price, along with the cross-sectional variation of the distance variable. The statistically significant positive coefficient indicates that a rise in the price of oil has a bigger impact on price dispersion if two countries are far apart. This clearly lends support to the transportation cost story above. ${ }^{32}$

\section{Robustness Checks}

We examine the robustness of the results in various ways, including using (i) alternative samples, (ii) alternative measures of price dispersion, (iii) additional regressors, and (iv) an alternative estimator.

\section{Alternative Samples}

Our basic result is confirmed for a balanced panel data set reported in the first two columns of Table 6, where the set of city pairs is held constant over time by omitting from the sample any city without data for all of the years 1990-2005. A U-shape pattern is still apparent in the year effects included in the regression reported in column 1 and plotted in panel (1) at the bottom of the table, as well as in the significance of the time trends reported in column 2 . The last two columns in Table 6 report results when the sample is reduced by omitting multiple cities per country and including only one city per country. ${ }^{33}$ This reduces the number of observations by over half (i.e., from 88912 in column 3 of Table 2 to 37264 in column 3 of Table 6). Most coefficients are unaffected, with the exception of that for exchange rate variability which falls roughly in half. Again the year pattern is very similar to our benchmark results in Table 2.

\section{Alternative Measures Of Price Dispersion}

Table 7 reports results based on alternative measures of price dispersion, using the full world sample. Following Parsley and Wei (2002), one alternative measure controls for the possibility that the magnitude of the deviation from the law-of-one-price may depend on the type of product, by removing the mean of the price gap for each good across all city pairs:

\footnotetext{
${ }^{32}$ We note that the coefficient on oil prices not interacted with distance switches from a positive to a negative value. This might reflect a nonlinear relationship between oil prices and price dispersion. In another (unreported) regression we added an interaction term involving oil prices and the same country variable. The negative coefficient obtained implies that the effect of oil prices is greater across international borders than within countries, also suggesting that oil effects on price dispersion are greater for cities pairs separated by greater distance.

${ }^{33}$ We use the cities in each country used by Parsley and Wei (2005, Appendix Table 2), which were generally capitol cities. We use New York City in the case of the United States.
} 


$$
\text { Demeaned-MSE }{ }_{i j, t}=\sum_{k \in K}\left(q_{i j, t}^{k}-q_{i j, t}^{k}\right)^{2} / K_{T} \text {, where } q_{i j, t}^{k} \equiv \sum_{i j \in \mathrm{C}} q_{i j, t}^{k} / C_{T}
$$

As our second measure, we calculate the mean absolute difference in the price spread between cities:

$$
\operatorname{MAD}_{i j, t}=\sum_{k \in K}\left|q_{i j, t}^{k}\right| / K_{T}
$$

The results with these alternative regressands in Table 7 again confirm our basic finding of a Ushaped time pattern in price dispersion.

\section{$\underline{\text { Additional Regressor Variables }}$}

Table 8 investigates the robustness of our basic result to including the effects of cost differences across countries, as captured either by international differences in GDP per capita, GDP, or wages. ${ }^{34}$ These variables are defined as absolute percent differences across countries. As expected, greater cost gaps lead to greater price dispersion. But once again the U-shaped pattern is confirmed. ${ }^{35}$

\section{Alternative Estimator}

Lastly, we consider in Table 9 an alternative estimator using city-pair fixed effects rather than city fixed effects. Of course, only coefficient values are reported for time-varying variables. The U-shaped time pattern withstands this robustness check as well.

\section{Conclusion}

This paper documents significant time-variation in the degree of global price convergence over the last two decades. In particular, there appears to be a general U-shaped pattern with rising price dispersion in recent years, a pattern which is remarkably robust across country groupings and commodity groups. This time-variation is difficult to explain in terms of the gravity explanatory variables common in the literature, as these tend not to vary much over time. However, regression analysis indicates that this time-varying pattern coincides well with oil price and transport costs fluctuations, which clearly are time varying. As a result, this paper offers direct new evidence on the role of transportation costs in driving international price dispersion.

\footnotetext{
${ }^{34}$ The wage data come from the EIU database; the GDP per capita and GDP data were obtained from the WDI (2005) and end in 2003.

${ }^{35}$ We also explored the role of possible nonlinearities by including quadratic terms involving distance and Rexchange rate volatility. None of the results from these exercises affected the U-shaped patterns of price dispersion.
} 
Further work remains. While the U-shaped profile of price dispersion over time is robust across regional subsets of the data, the main explanation offered here, a rise in transportation costs, applies only in cases where cities of different regions are trading. So the rising price dispersion within Europe, the United States, and East Asia remain unexplained. In addition, more analysis is warranted on possible dynamic effects of the determinants of price dispersion, with such effects perhaps persisting to varying degrees over time. Exploiting differences between the pattern of price dispersion and degree of transportability within and across different commodity groups may also provide more insight. 


\section{References}

Anderson, James E. and Eric van Wincoop, 2004, “Trade Costs,” Journal of Economic Literature 42, 691-751.

Bergin, Paul and Reuven Glick, 2005. “Tradability, Productivity, and Understanding International Economic Integration,” NBER Working Paper 11637.

Corsetti, G. and L. Dedola, 2005. “A Macroeconomic Model of International Price Discrimination,” Journal of International Economics 67, 129-155.

Crucini, Mario J., Chris I. Telmer and Marios Zachariadis, 2005. "Understanding European Real Exchange Rates,” American Economic Review 95, 724-738.

Crucini, Mario J. and Mototsugu Shintani, 2006. "Persistence in Law-of-One-Price Deviations: Evidence from Micro-data,” Vanderbilt University Working Paper No. 06-W16, July.

Crucini, Mario J., Chris I. Telmer and Marios Zachariadis, 2003. "Price Dispersion: The Role of Borders, Distance and Location,” Unpublished working paper.

Engel, Charles and John H. Rogers, 2004. "European Product Market Integration after the Euro,” Economic Policy 39, 347-384.

Engel, Charles, John H. Rogers, and Shing-Yi Wang, 2003. “ Revisiting the Border: Assessment of the Law of One Price Using Very Disaggregated Consumer Price Data,” Federal Reserve Board International Finance Discussion Paper No. 777, September.

Glick, Reuven, Xueyan Guo, and Michael Hutchison, 2006. "Currency Crises, Capital Account Liberalization, and Selection Bias,” Review of Economics and Statistics 88, 698-714..

Glick, Reuven and Andrew Rose, 2002. "Does a Currency Union Affect Trade? The Time Series Evidence,” European Economic Review 46, 1125-1151.

Hummels, David, 1999a, “Have International Transportation Costs Declined?” working paper, Purdue University. , 1999b. “Toward a Geography of Trade Costs,” working paper, Purdue University. , 2001. “Time as a Trade Barrier,” working paper, Purdue University.

Lothian, James R., 2001. “Financial Integration Over the Past Three Centuries,” Bancaria, No. 9. , 2006. "Institutions, Capital Flows and Financial Integration, ”Journal of International Money and Finance, April, 358-369.

Parsley, David and Shang-jin Wei, 2002. "Currency Arrangements and Goods Market Integration: A Price Based Approach,” Unpublished working paper. 
Table 1: Statistical Tests for Change in Price Dispersion

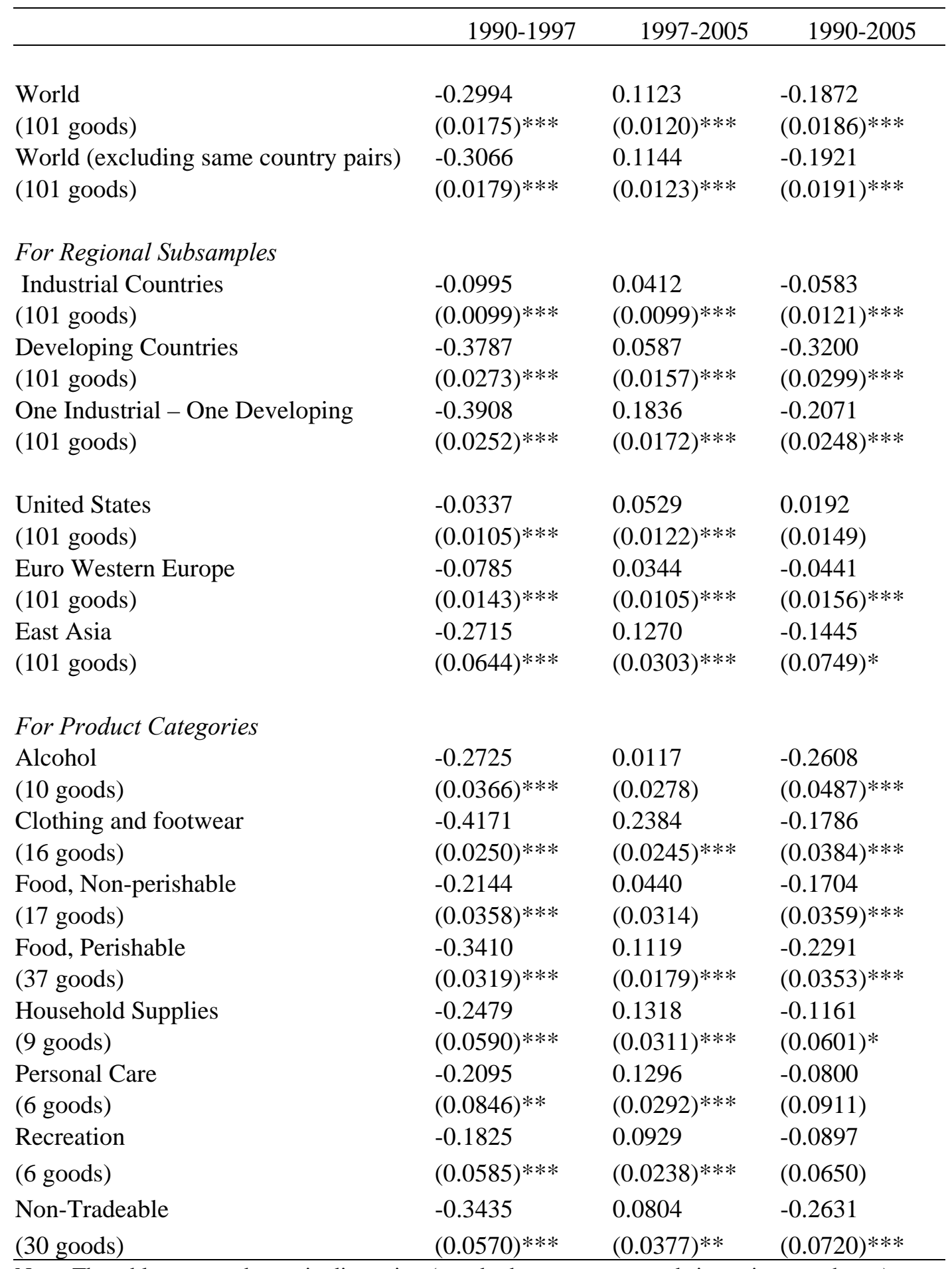

Note: The table reports change in dispersion (standard error across goods items in parentheses).

Significance at $1 \%, 5 \%, 10 \%$ indicated by $* * *,{ }^{* *}$, and $*$, respectively. 
Table 2: Regression Results for Full World Sample

\begin{tabular}{|c|c|c|c|c|}
\hline & $(1)$ & $(2)$ & $(3)$ & $(4)$ \\
\hline \multirow[t]{2}{*}{ log distance } & 0.032 & 0.032 & 0.032 & 0.032 \\
\hline & $(0.004)^{* * *}$ & $(0.004)^{* * *}$ & $(0.004)^{* * *}$ & $(0.004)^{* * *}$ \\
\hline \multirow[t]{2}{*}{ border } & -0.034 & -0.033 & -0.033 & -0.032 \\
\hline & $(0.015)^{* *}$ & $(0.015)^{* *}$ & $(0.015)^{* *}$ & $(0.015)^{* *}$ \\
\hline \multirow[t]{2}{*}{ common language } & -0.032 & -0.032 & -0.034 & -0.034 \\
\hline & $(0.007)^{* * *}$ & $(0.007)^{* * *}$ & $(0.007)^{* * *}$ & $(0.007)^{* * *}$ \\
\hline \multirow[t]{2}{*}{ tariffs } & 0.210 & 0.179 & 0.225 & 0.196 \\
\hline & $(0.053)^{* * *}$ & $(0.053) * * *$ & $(0.054)^{* * *}$ & $(0.054)^{* * *}$ \\
\hline \multirow[t]{2}{*}{ same country } & -0.092 & -0.096 & -0.082 & -0.086 \\
\hline & $(0.019)^{* * *}$ & $(0.019)^{* * *}$ & $(0.018)^{* * *}$ & $(0.019)^{* * *}$ \\
\hline \multirow[t]{2}{*}{ regional trade agreement } & -0.091 & -0.094 & -0.084 & -0.088 \\
\hline & $(0.011)^{* * *}$ & $(0.011)^{* * *}$ & $(0.011)^{* * *}$ & $(0.011)^{* * *}$ \\
\hline \multirow[t]{2}{*}{ currency union } & -0.047 & -0.042 & -0.043 & -0.038 \\
\hline & $(0.007)^{* * *}$ & $(0.007)^{* * *}$ & $(0.007)^{* * *}$ & $(0.007)^{* * *}$ \\
\hline \multirow[t]{2}{*}{ currency crisis } & & & 0.033 & 0.031 \\
\hline & & & $(0.003)^{* * *}$ & $(0.003)^{* * *}$ \\
\hline \multirow[t]{2}{*}{ exchange rate volatility } & & & 0.232 & 0.245 \\
\hline & & & $(0.024)^{* * *}$ & $(0.024)^{* * *}$ \\
\hline \multirow[t]{2}{*}{ trend 1990-1997 } & & -0.037 & & -0.034 \\
\hline & & $(0.001)^{* * *}$ & & $(0.001)^{* * *}$ \\
\hline \multirow[t]{2}{*}{ trend 1997-2005 } & & 0.019 & & 0.020 \\
\hline & & $(0.001)^{* * *}$ & & $(0.001)^{* * *}$ \\
\hline city fixed effects & yes & yes & yes & yes \\
\hline year fixed effects & yes & no & yes & no \\
\hline observations & 90218 & 90218 & 88912 & 88912 \\
\hline adjusted R-squared & 0.58 & 0.57 & 0.59 & 0.58 \\
\hline
\end{tabular}

Note: Robust standard errors in parentheses. Significance at 1\%, 5\%, $10 \%$ indicated by ***, **, and $*$, respectively. Constant not reported.

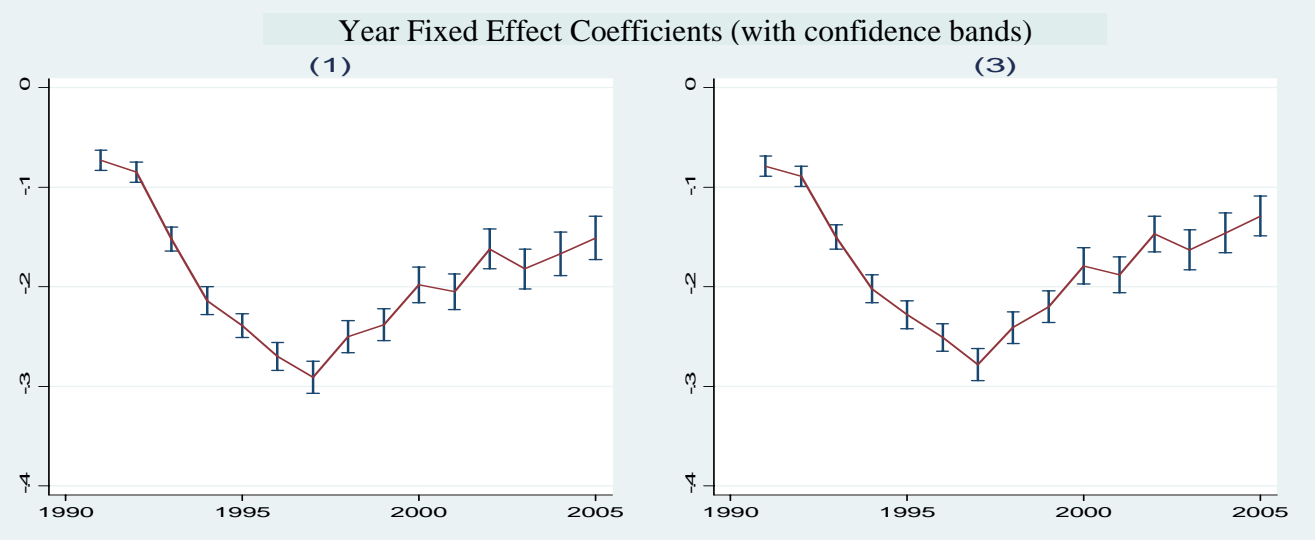


Table 3: Regression Results for Regional City Pairs

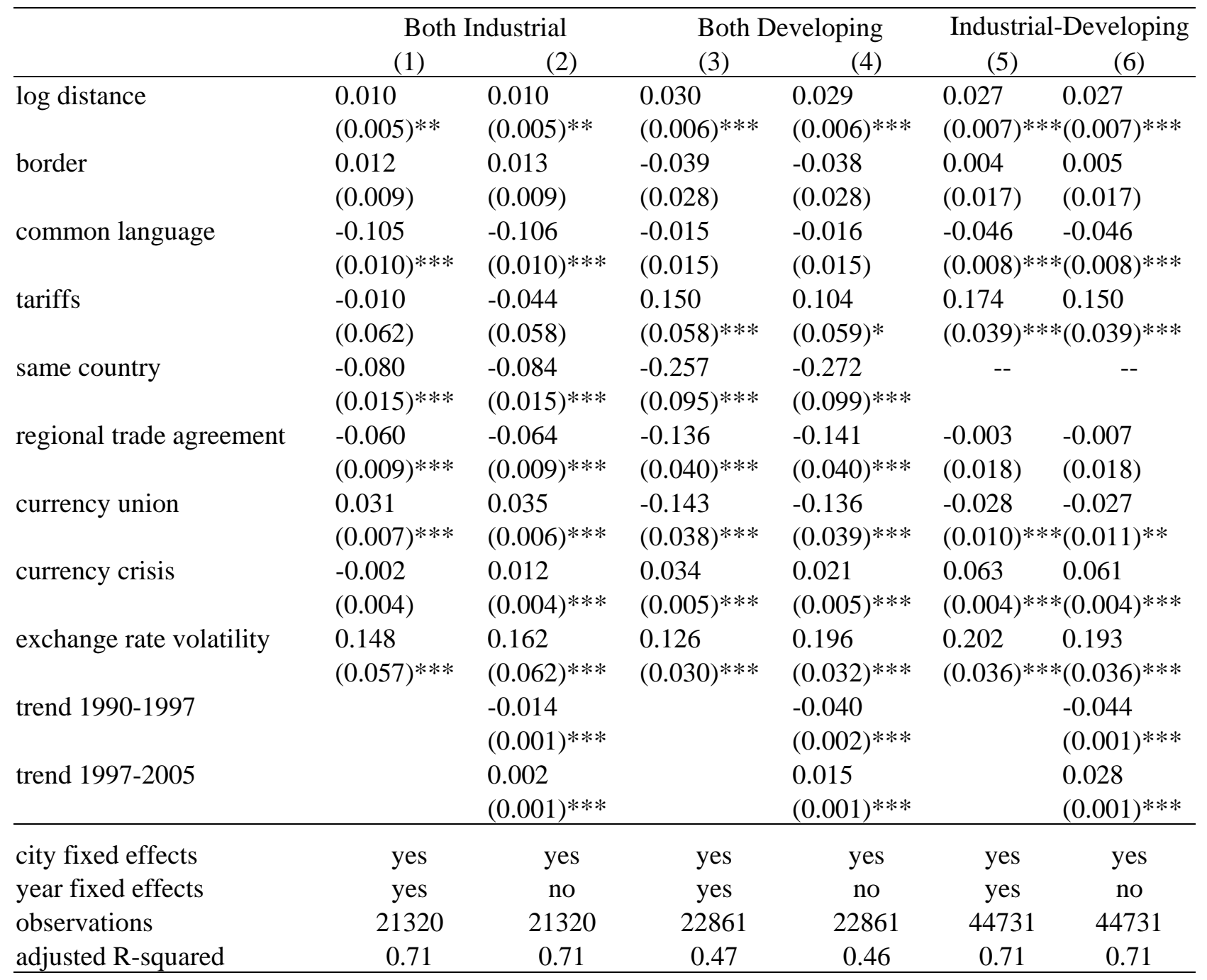

Note: Robust standard errors in parentheses. Significance at $1 \%, 5 \%, 10 \%$ indicated by $* * *$, **, and *, respectively. Constant not reported.

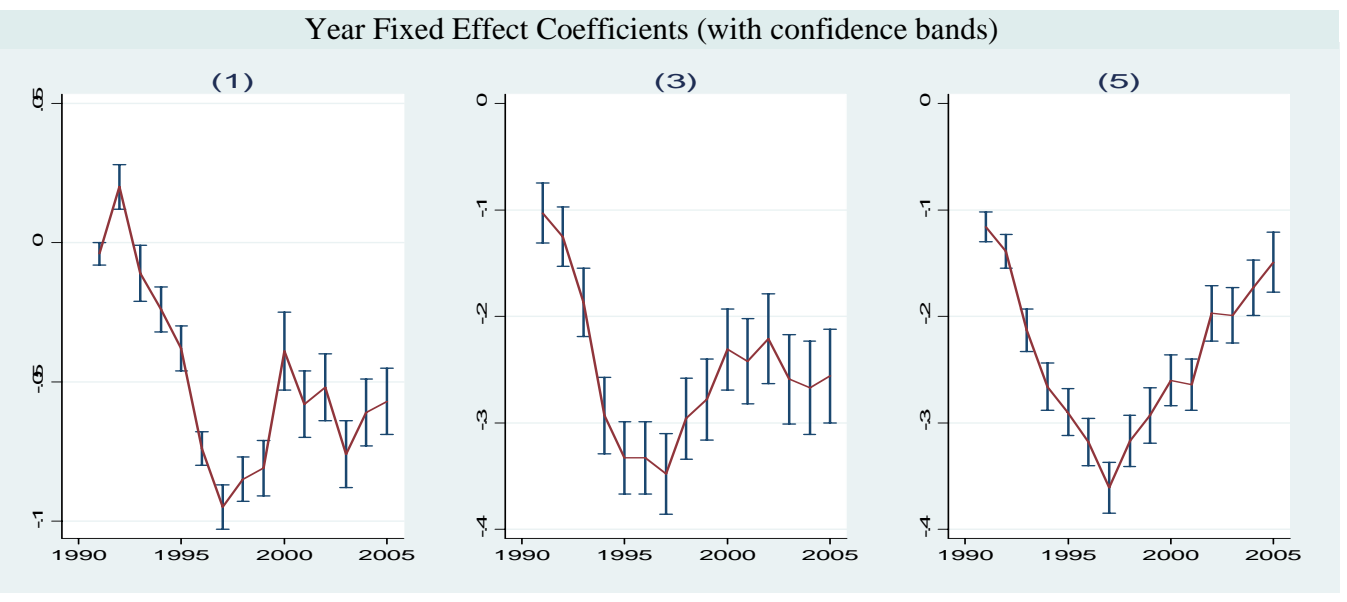


Table 4: Regression Results for Other City Pairs

\begin{tabular}{|c|c|c|c|c|c|c|}
\hline & \multicolumn{2}{|c|}{ Eurozone } & \multicolumn{2}{|c|}{ United States } & \multicolumn{2}{|c|}{ East Asia (incl. Japan) } \\
\hline & $(1)$ & $(2)$ & (3) & $(4)$ & (5) & $(6)$ \\
\hline log distance & $\begin{array}{l}0.012 \\
(0.006)^{*}\end{array}$ & $\begin{array}{l}0.012 \\
(0.006)^{*}\end{array}$ & $\begin{array}{l}0.004 \\
(0.002)^{* *}\end{array}$ & $\begin{array}{l}0.004 \\
(0.002)^{* *}\end{array}$ & $\begin{array}{l}0.075 \\
(0.056)\end{array}$ & $\begin{array}{l}0.083 \\
(0.056)\end{array}$ \\
\hline border & $\begin{array}{l}-0.008 \\
(0.006)\end{array}$ & $\begin{array}{l}-0.010 \\
(0.007)\end{array}$ & -- & -- & $\begin{array}{l}0.077 \\
(0.086)\end{array}$ & $\begin{array}{l}0.073 \\
(0.087)\end{array}$ \\
\hline common language & $\begin{array}{l}0.003 \\
(0.009)\end{array}$ & $\begin{array}{l}0.002 \\
(0.009)\end{array}$ & -- & -- & $\begin{array}{l}0.076 \\
(0.071)\end{array}$ & $\begin{array}{l}0.072 \\
(0.072)\end{array}$ \\
\hline tariffs & $\begin{array}{l}0.449 \\
(0.561)\end{array}$ & $\begin{array}{l}0.568 \\
(0.626)\end{array}$ & -- & -- & $\begin{array}{l}-0.613 \\
(0.271)^{* *}\end{array}$ & $\begin{array}{l}-0.491 \\
(0.248)^{*}\end{array}$ \\
\hline same country & $\begin{array}{l}-0.039 \\
(0.113)\end{array}$ & $\begin{array}{l}-0.022 \\
(0.124)\end{array}$ & -- & -- & $\begin{array}{l}-0.700 \\
(0.261)^{* * *}\end{array}$ & $\begin{array}{l}-0.666 \\
(0.258)^{* *}\end{array}$ \\
\hline regional trade agreement & $\begin{array}{l}0.028 \\
(0.107)\end{array}$ & $\begin{array}{l}0.050 \\
(0.119)\end{array}$ & -- & -- & $\begin{array}{l}-0.459 \\
(0.124) * * *\end{array}$ & $\begin{array}{l}-0.426 \\
(0.120)^{* * *}\end{array}$ \\
\hline currency union & $\begin{array}{l}-0.016 \\
(0.010)\end{array}$ & $\begin{array}{l}-0.012 \\
(0.005)^{* *}\end{array}$ & -- & -- & $\begin{array}{l}0.163 \\
(0.077)^{* *}\end{array}$ & $\begin{array}{l}0.177 \\
(0.077)^{* *}\end{array}$ \\
\hline currency crisis & $\begin{array}{l}0.043 \\
(0.007)^{* * *}\end{array}$ & $\begin{array}{l}0.037 \\
(0.007)^{* * *}\end{array}$ & -- & -- & $\begin{array}{l}0.040 \\
(0.029)\end{array}$ & $\begin{array}{l}-0.033 \\
(0.019)^{*}\end{array}$ \\
\hline exchange rate volatility & $\begin{array}{l}0.149 \\
(0.291)\end{array}$ & $\begin{array}{l}-0.854 \\
(0.281)^{* * *}\end{array}$ & -- & -- & $\begin{array}{l}1.417 \\
(0.200) * * *\end{array}$ & $\begin{array}{l}1.380 \\
(0.148)^{* * *}\end{array}$ \\
\hline trend 1990-1997 & & $\begin{array}{l}-0.009 \\
(0.001)^{* * *}\end{array}$ & & $\begin{array}{l}-0.010 \\
(0.001)^{* * *}\end{array}$ & & $\begin{array}{l}-0.029 \\
(0.007)^{* * *}\end{array}$ \\
\hline trend 1997-2005 & & $\begin{array}{l}0.008 \\
(0.001)^{* * *}\end{array}$ & & $\begin{array}{l}0.007 \\
(0.001)^{* * *}\end{array}$ & & $\begin{array}{l}0.014 \\
(0.006)^{* *}\end{array}$ \\
\hline city fixed effects & yes & yes & yes & yes & yes & yes \\
\hline year fixed effects & yes & no & yes & no & yes & no \\
\hline observations & 2432 & 2432 & 1652 & 1652 & 1179 & 1179 \\
\hline adjusted R-squared & 0.59 & 0.56 & 0.5 & 0.43 & 0.63 & 0.62 \\
\hline
\end{tabular}

Note: Robust standard errors in parentheses. Significance at 1\%, 5\%, 10\% indicated by $* * *, * *$, and $*$, respectively. Constant not reported.
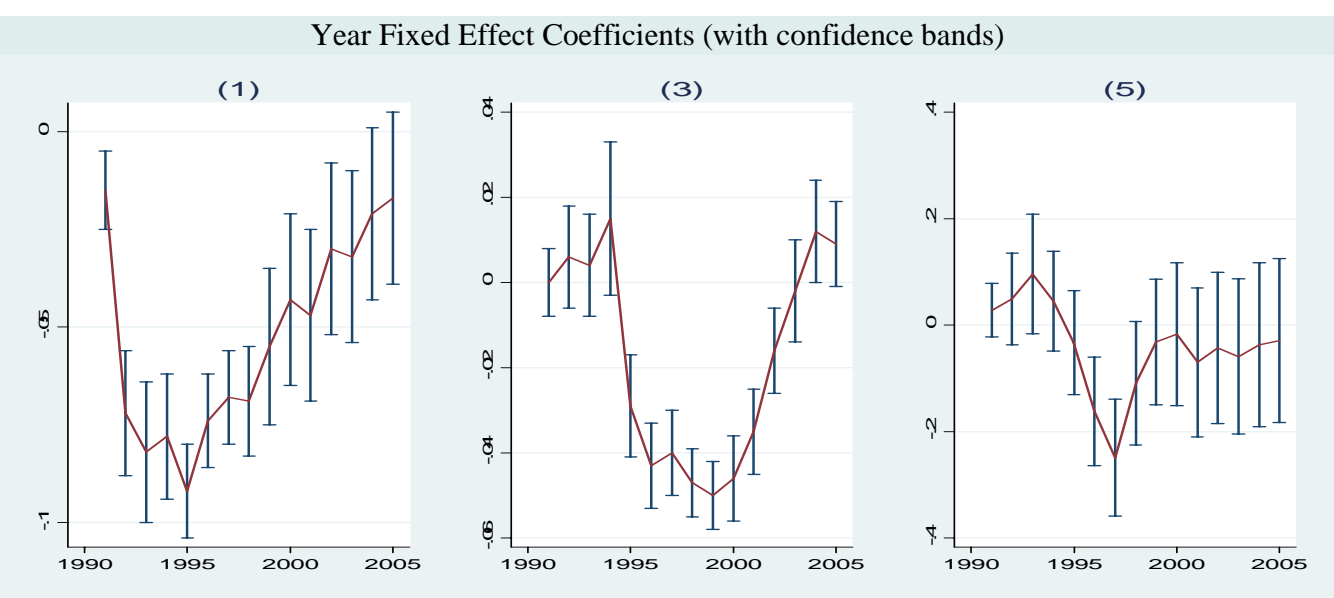
Table 5: Regression Results with Oil Price

\begin{tabular}{|c|c|c|c|c|c|}
\hline & $\begin{array}{c}\text { World } \\
(1)\end{array}$ & $\begin{array}{c}\text { Both } \\
\text { Industrial } \\
(2) \\
\end{array}$ & $\begin{array}{c}\text { Both } \\
\text { Developing } \\
(3)\end{array}$ & $\begin{array}{c}\text { Industrial- } \\
\text { Developing } \\
(4) \\
\end{array}$ & $\begin{array}{c}\text { World } \\
\text { w/interaction } \\
(5) \\
\end{array}$ \\
\hline log distance & $\begin{array}{l}0.031 \\
(0.004) * * *\end{array}$ & $\begin{array}{l}0.009 \\
(0.005)^{*}\end{array}$ & $\begin{array}{l}0.029 \\
(0.006)^{* * *}\end{array}$ & $\begin{array}{l}0.026 \\
(0.007)^{* * *}\end{array}$ & $\begin{array}{l}0.067 \\
(0.006) * * *\end{array}$ \\
\hline border & $\begin{array}{l}-0.033 \\
(0.015)^{* *}\end{array}$ & $\begin{array}{l}0.004 \\
-0.009\end{array}$ & $\begin{array}{l}-0.034 \\
-0.028\end{array}$ & $\begin{array}{l}0.008 \\
-0.017\end{array}$ & $\begin{array}{l}-0.033 \\
(0.015)^{* *}\end{array}$ \\
\hline common language & $\begin{array}{l}-0.034 \\
(0.007)^{* * *}\end{array}$ & $\begin{array}{l}-0.106 \\
(0.010)^{* * *}\end{array}$ & $\begin{array}{l}-0.015 \\
-0.015\end{array}$ & $\begin{array}{l}-0.045 \\
(0.008) * * *\end{array}$ & $\begin{array}{l}-0.034 \\
(0.007)^{* * *}\end{array}$ \\
\hline tariffs & $\begin{array}{l}0.415 \\
(0.039)^{* * *}\end{array}$ & $\begin{array}{l}0.4 \\
(0.040)^{* * *}\end{array}$ & $\begin{array}{l}0.343 \\
(0.043) * * *\end{array}$ & $\begin{array}{l}0.45 \\
(0.031)^{* * *}\end{array}$ & $\begin{array}{l}0.42 \\
(0.039) * * *\end{array}$ \\
\hline same country & $\begin{array}{l}-0.059 \\
(0.019)^{* * *}\end{array}$ & $\begin{array}{l}-0.033 \\
(0.014)^{* *}\end{array}$ & $\begin{array}{l}-0.175 \\
(0.085)^{* *}\end{array}$ & $\begin{array}{l}0 \\
0\end{array}$ & $\begin{array}{l}-0.057 \\
(0.019)^{* * *}\end{array}$ \\
\hline regional trade agreement & $\begin{array}{l}-0.079 \\
(0.011)^{* * * *}\end{array}$ & $\begin{array}{l}-0.032 \\
(0.009)^{* * * *}\end{array}$ & $\begin{array}{l}-0.155 \\
(0.040)^{* * * *}\end{array}$ & $\begin{array}{l}-0.02 \\
-0.017\end{array}$ & $\begin{array}{l}-0.078 \\
(0.011)^{* * *}\end{array}$ \\
\hline currency union & $\begin{array}{l}-0.051 \\
(0.006)^{* * *}\end{array}$ & $\begin{array}{l}0.017 \\
(0.006)^{* * *}\end{array}$ & $\begin{array}{l}-0.147 \\
(0.036)^{* * *}\end{array}$ & $\begin{array}{l}-0.038 \\
(0.011)^{* * *}\end{array}$ & $\begin{array}{l}-0.046 \\
(0.006)^{* * *}\end{array}$ \\
\hline currency crisis & $\begin{array}{l}0.041 \\
(0.003)^{* * * *}\end{array}$ & $\begin{array}{l}0.029 \\
(0.004) * * *\end{array}$ & $\begin{array}{l}0.012 \\
(0.005)^{* *}\end{array}$ & $\begin{array}{l}0.07 \\
(0.005)^{* * * *}\end{array}$ & $\begin{array}{l}0.346 \\
(0.027)^{* * *}\end{array}$ \\
\hline exchange rate volatility & $\begin{array}{l}0.344 \\
(0.027)^{* * * *}\end{array}$ & $\begin{array}{l}0.169 \\
(0.067)^{* *}\end{array}$ & $\begin{array}{l}0.318 \\
(0.033) * * *\end{array}$ & $\begin{array}{l}0.359 \\
(0.039) * * *\end{array}$ & $\begin{array}{l}0.041 \\
(0.003)^{* * *}\end{array}$ \\
\hline log oil price & $\begin{array}{l}0.127 \\
(0.005)^{* * * *}\end{array}$ & $\begin{array}{l}0.027 \\
(0.004) * * *\end{array}$ & $\begin{array}{l}0.085 \\
(0.008) * * *\end{array}$ & $\begin{array}{l}0.187 \\
(0.005)^{* * * *}\end{array}$ & $\begin{array}{l}-0.079 \\
(0.024) * * *\end{array}$ \\
\hline $\log$ oil price $* \log$ distance & & & & & $\begin{array}{l}0.025 \\
(0.003)^{* * *}\end{array}$ \\
\hline city fixed effects & yes & yes & yes & yes & yes \\
\hline year fixed effects & no & no & no & no & no \\
\hline observations & 88912 & 21320 & 22861 & 44731 & 88912 \\
\hline adjusted R-squared & 0.56 & 0.7 & 0.42 & 0.69 & 0.56 \\
\hline \multicolumn{6}{|c|}{ OLS coefficients of residuals on trends: } \\
\hline trend 1990-1997 & $\begin{array}{l}-0.026 \\
(0.001)^{* * *}\end{array}$ & $\begin{array}{l}-0.032 \\
(0.001)^{* * *}\end{array}$ & $\begin{array}{l}-0.029 \\
(0.001)^{* * *}\end{array}$ & $\begin{array}{l}-0.021 \\
(0.001)^{* * *}\end{array}$ & $\begin{array}{l}-0.026 \\
(0.001)^{* * *}\end{array}$ \\
\hline trend 1997-2005 & $\begin{array}{l}0.010 \\
(0.000)^{* * * *}\end{array}$ & $\begin{array}{l}0.019 \\
(0.000)^{* * *}\end{array}$ & $\begin{array}{l}0.014 \\
(0.000)^{* * *}\end{array}$ & $\begin{array}{l}0.003 \\
(0.000)^{* * *}\end{array}$ & $\begin{array}{l}0.010 \\
(0.000)^{* * *}\end{array}$ \\
\hline
\end{tabular}

Note: See Table 2. Coefficients from Regression of Residuals on Year Dummies (with confidence bands)
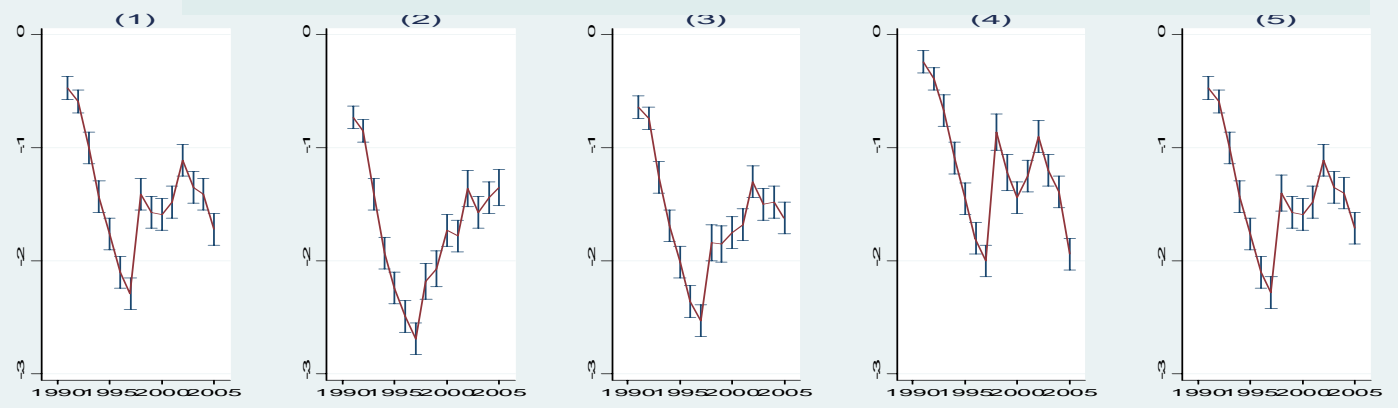
Table 6: Regression Results for Alternative Samples

\begin{tabular}{|c|c|c|c|c|}
\hline & \multicolumn{2}{|c|}{ Balanced World } & \multicolumn{2}{|c|}{ One City per Country } \\
\hline & $(1)$ & $(2)$ & (3) & $(4)$ \\
\hline log distance & $\begin{array}{l}0.037 \\
(0.005)^{* * *}\end{array}$ & $\begin{array}{l}0.037 \\
(0.005) * * *\end{array}$ & $\begin{array}{l}0.038 \\
(0.007) * * *\end{array}$ & $\begin{array}{l}0.038 \\
(0.007)^{* * *}\end{array}$ \\
\hline border & $\begin{array}{l}-0.030 \\
(0.018)^{*}\end{array}$ & $\begin{array}{l}-0.029 \\
(0.018)\end{array}$ & $\begin{array}{l}-0.073 \\
(0.030)^{* *}\end{array}$ & $\begin{array}{l}-0.073 \\
(0.030)^{* *}\end{array}$ \\
\hline common language & $\begin{array}{l}-0.034 \\
(0.008)^{* * *}\end{array}$ & $\begin{array}{l}-0.034 \\
(0.008) * * *\end{array}$ & $\begin{array}{l}-0.032 \\
(0.012)^{* * *}\end{array}$ & $\begin{array}{l}-0.033 \\
(0.012)^{* * *}\end{array}$ \\
\hline tariffs & $\begin{array}{l}0.202 \\
(0.072)^{* * *}\end{array}$ & $\begin{array}{l}0.179 \\
(0.071)^{* *}\end{array}$ & $\begin{array}{l}0.102 \\
(0.039)^{* * *}\end{array}$ & $\begin{array}{l}0.073 \\
(0.039)^{*}\end{array}$ \\
\hline same country & $\begin{array}{l}-0.074 \\
(0.022)^{* * *}\end{array}$ & $\begin{array}{l}-0.077 \\
(0.022)^{* * *}\end{array}$ & -- & -- \\
\hline regional trade agreement & $\begin{array}{l}-0.085 \\
(0.012) * * *\end{array}$ & $\begin{array}{l}-0.089 \\
(0.012)^{* * *}\end{array}$ & $\begin{array}{l}-0.157 \\
(0.018) * * *\end{array}$ & $\begin{array}{l}-0.162 \\
(0.018) * * *\end{array}$ \\
\hline currency union & $\begin{array}{l}-0.039 \\
(0.008)^{* * *}\end{array}$ & $\begin{array}{l}-0.034 \\
(0.008)^{* * *}\end{array}$ & $\begin{array}{l}-0.053 \\
(0.013)^{* * *}\end{array}$ & $\begin{array}{l}-0.046 \\
(0.013)^{* * *}\end{array}$ \\
\hline currency crisis & $\begin{array}{l}0.031 \\
(0.004)^{* * *}\end{array}$ & $\begin{array}{l}0.030 \\
(0.003)^{* * *}\end{array}$ & $\begin{array}{l}0.032 \\
(0.004) * * *\end{array}$ & $\begin{array}{l}0.029 \\
(0.004)^{* * *}\end{array}$ \\
\hline exchange rate volatility & $\begin{array}{l}0.171 \\
(0.023)^{* * *}\end{array}$ & $\begin{array}{l}0.181 \\
(0.024)^{* * *}\end{array}$ & $\begin{array}{l}0.134 \\
(0.027)^{* * *}\end{array}$ & $\begin{array}{l}0.137 \\
(0.027)^{* * *}\end{array}$ \\
\hline trend 1990-1997 & & $\begin{array}{l}-0.036 \\
(0.001)^{* * *}\end{array}$ & & $\begin{array}{l}-0.045 \\
(0.001)^{* * *}\end{array}$ \\
\hline trend 1997-2005 & & $\begin{array}{l}0.020 \\
(0.001)^{* * *}\end{array}$ & & $\begin{array}{l}0.021 \\
(0.001)^{* * *}\end{array}$ \\
\hline city fixed effects & yes & yes & yes & yes \\
\hline year fixed effects & yes & no & yes & no \\
\hline observations & 73457 & 73457 & 37264 & 37264 \\
\hline adjusted R-squared & 0.59 & 0.59 & 0.49 & 0.49 \\
\hline
\end{tabular}

Note: Robust standard errors in parentheses. Significance at $1 \%, 5 \%, 10 \%$ indicated by $* * *$, **, and *, respectively. Constant not reported.

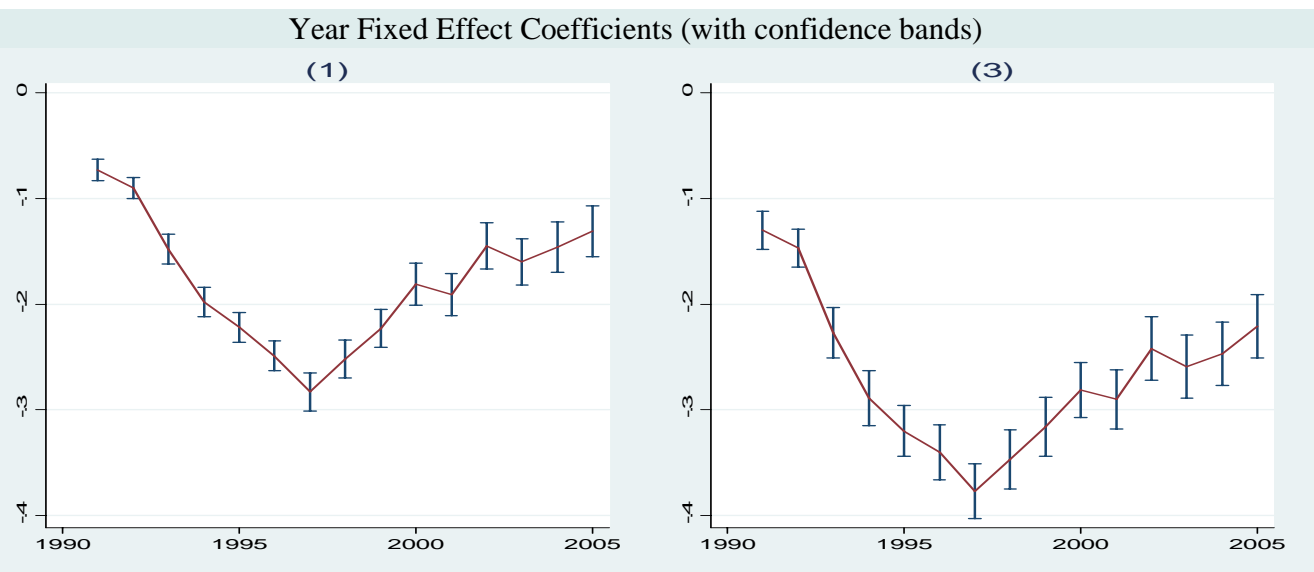


Table 7: Regression Results with Alternative Measures of Price Dispersion, Full World Sample

\begin{tabular}{|c|c|c|c|c|}
\hline & $\begin{array}{l}\text { Demeaned } \\
\text { MSE } \\
\text { (1) }\end{array}$ & $\begin{array}{l}\text { Demeaned } \\
\text { MSE } \\
\text { (2) }\end{array}$ & $\begin{array}{l}\text { Mean } \\
\text { Absolute } \\
\text { Difference } \\
\quad(3)\end{array}$ & $\begin{array}{l}\text { Mean } \\
\text { Absolute } \\
\text { Difference } \\
\quad(4)\end{array}$ \\
\hline log distance & $\begin{array}{l}0.032 \\
(0.004)^{* * *}\end{array}$ & $\begin{array}{l}0.032 \\
(0.004)^{* * *}\end{array}$ & $\begin{array}{l}0.019 \\
(0.002)^{* * *}\end{array}$ & $\begin{array}{l}0.019 \\
(0.002)^{* * *}\end{array}$ \\
\hline border & $\begin{array}{l}-0.031 \\
(0.015)^{* *}\end{array}$ & $\begin{array}{l}-0.03 \\
(0.015)^{* *}\end{array}$ & $\begin{array}{l}-0.026 \\
(0.008)^{* * *}\end{array}$ & $\begin{array}{l}-0.026 \\
(0.008)^{* * *}\end{array}$ \\
\hline common language & $\begin{array}{l}-0.038 \\
(0.007)^{* * *}\end{array}$ & $\begin{array}{l}-0.038 \\
(0.007)^{* * *}\end{array}$ & $\begin{array}{l}-0.021 \\
(0.003)^{* * *}\end{array}$ & $\begin{array}{l}-0.021 \\
(0.003)^{* * *}\end{array}$ \\
\hline tariffs & $\begin{array}{l}0.215 \\
(0.056)^{* * *}\end{array}$ & $\begin{array}{l}0.188 \\
(0.056)^{* * *}\end{array}$ & $\begin{array}{l}0.098 \\
(0.025)^{* * *}\end{array}$ & $\begin{array}{l}0.085 \\
(0.025)^{* * *}\end{array}$ \\
\hline same country & $\begin{array}{l}-0.044 \\
(0.019)^{* *}\end{array}$ & $\begin{array}{l}-0.047 \\
(0.019)^{* *}\end{array}$ & $\begin{array}{l}-0.11 \\
(0.010)^{* * *}\end{array}$ & $\begin{array}{l}-0.112 \\
(0.010)^{* * *}\end{array}$ \\
\hline regional trade agreement & $\begin{array}{l}-0.084 \\
(0.011)^{* * *}\end{array}$ & $\begin{array}{l}-0.087 \\
(0.011)^{* * *}\end{array}$ & $\begin{array}{l}-0.072 \\
(0.006)^{* * *}\end{array}$ & $\begin{array}{l}-0.074 \\
(0.006)^{* * *}\end{array}$ \\
\hline currency union & $\begin{array}{l}-0.04 \\
(0.007)^{* * *}\end{array}$ & $\begin{array}{l}-0.036 \\
(0.007)^{* * *}\end{array}$ & $\begin{array}{l}-0.028 \\
(0.004)^{* * *}\end{array}$ & $\begin{array}{l}-0.025 \\
(0.004)^{* * *}\end{array}$ \\
\hline currency crisis & $\begin{array}{l}0.034 \\
(0.003)^{* * *}\end{array}$ & $\begin{array}{l}0.033 \\
(0.003) * * *\end{array}$ & $\begin{array}{l}0.016 \\
(0.002)^{* * *}\end{array}$ & $\begin{array}{l}0.015 \\
(0.001)^{* * *}\end{array}$ \\
\hline exchange rate volatility & $\begin{array}{l}0.222 \\
(0.024) * * *\end{array}$ & $\begin{array}{l}0.235 \\
(0.024) * * *\end{array}$ & $\begin{array}{l}0.151 \\
(0.012)^{* * *}\end{array}$ & $\begin{array}{l}0.158 \\
(0.012)^{* * *}\end{array}$ \\
\hline trend 1990-1997 & & $\begin{array}{l}-0.034 \\
(0.001)^{* * *}\end{array}$ & & $\begin{array}{l}-0.018 \\
(0.000)^{* * *}\end{array}$ \\
\hline trend 1997-2005 & & $\begin{array}{l}0.020 \\
(0.001)^{* * *}\end{array}$ & & $\begin{array}{l}0.011 \\
(0.000)^{* * *}\end{array}$ \\
\hline city fixed effects & yes & yes & yes & yes \\
\hline year fixed effects & yes & no & yes & no \\
\hline observations & 88912 & 88912 & 88912 & 88912 \\
\hline adjusted R-squared & 0.59 & 0.59 & 0.63 & 0.63 \\
\hline
\end{tabular}


Table 8: Regression Results with Additional Regressors, Full World Sample

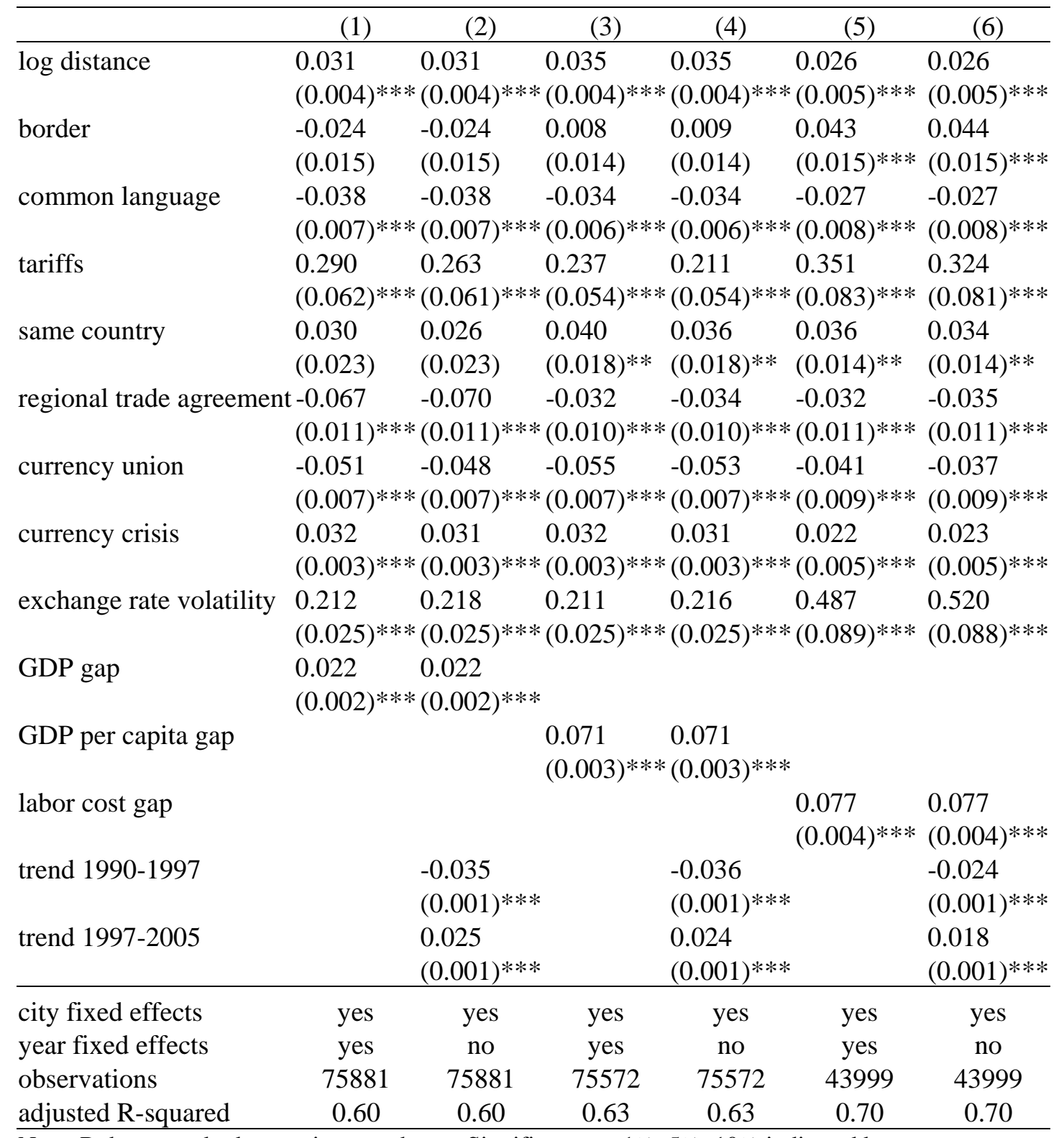

Note: Robust standard errors in parentheses. Significance at 1\%, 5\%, 10\% indicated by $* * *, * *$, and *, respectively. Regressions with GDP and GDP per capita are for period 1990-2003. Constant not reported. 
Table 9: Regression Results with City-Pair Fixed-Effect Estimator Full World Sample

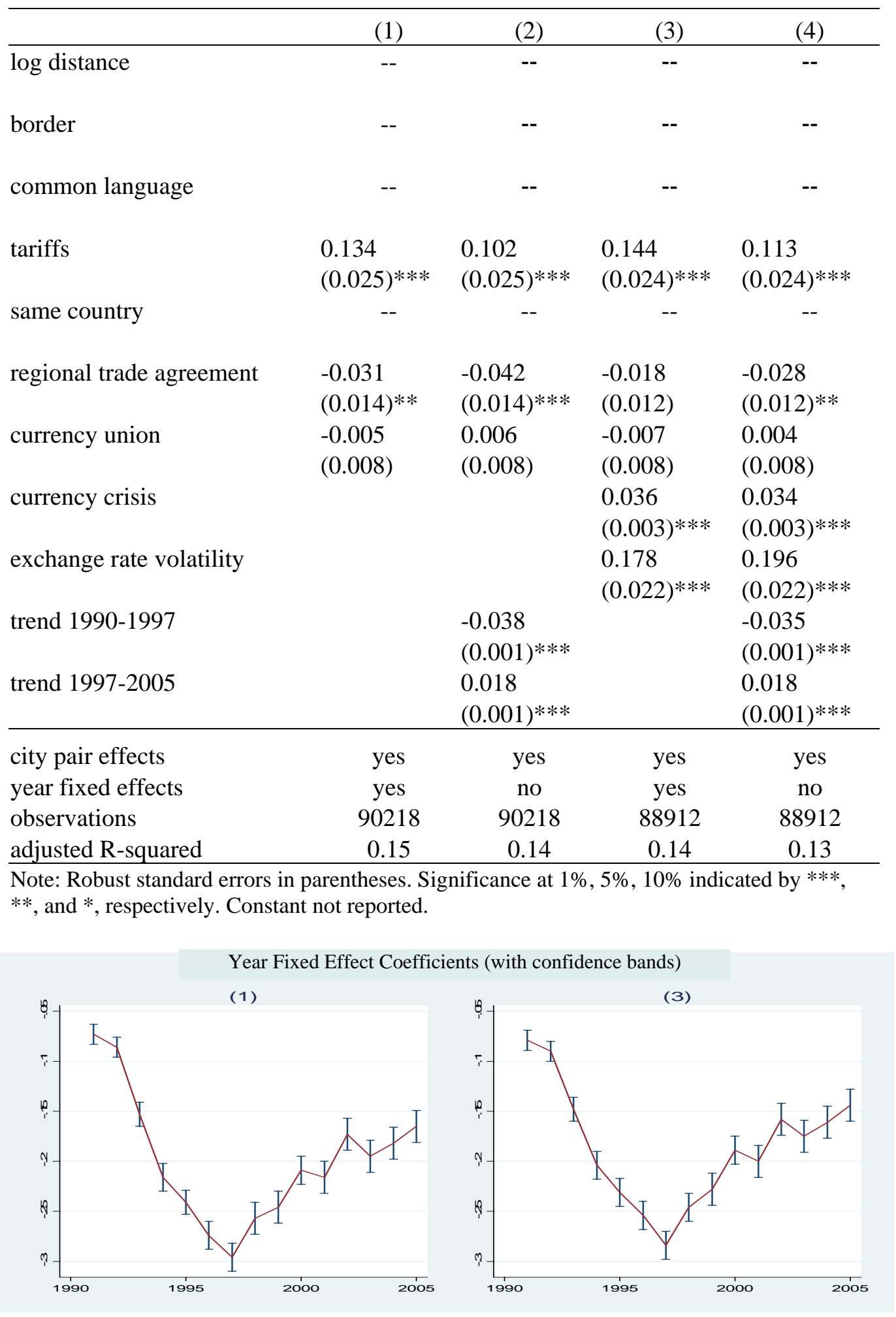




\section{Fig. 1. Price Dispersion for Full World Sample}

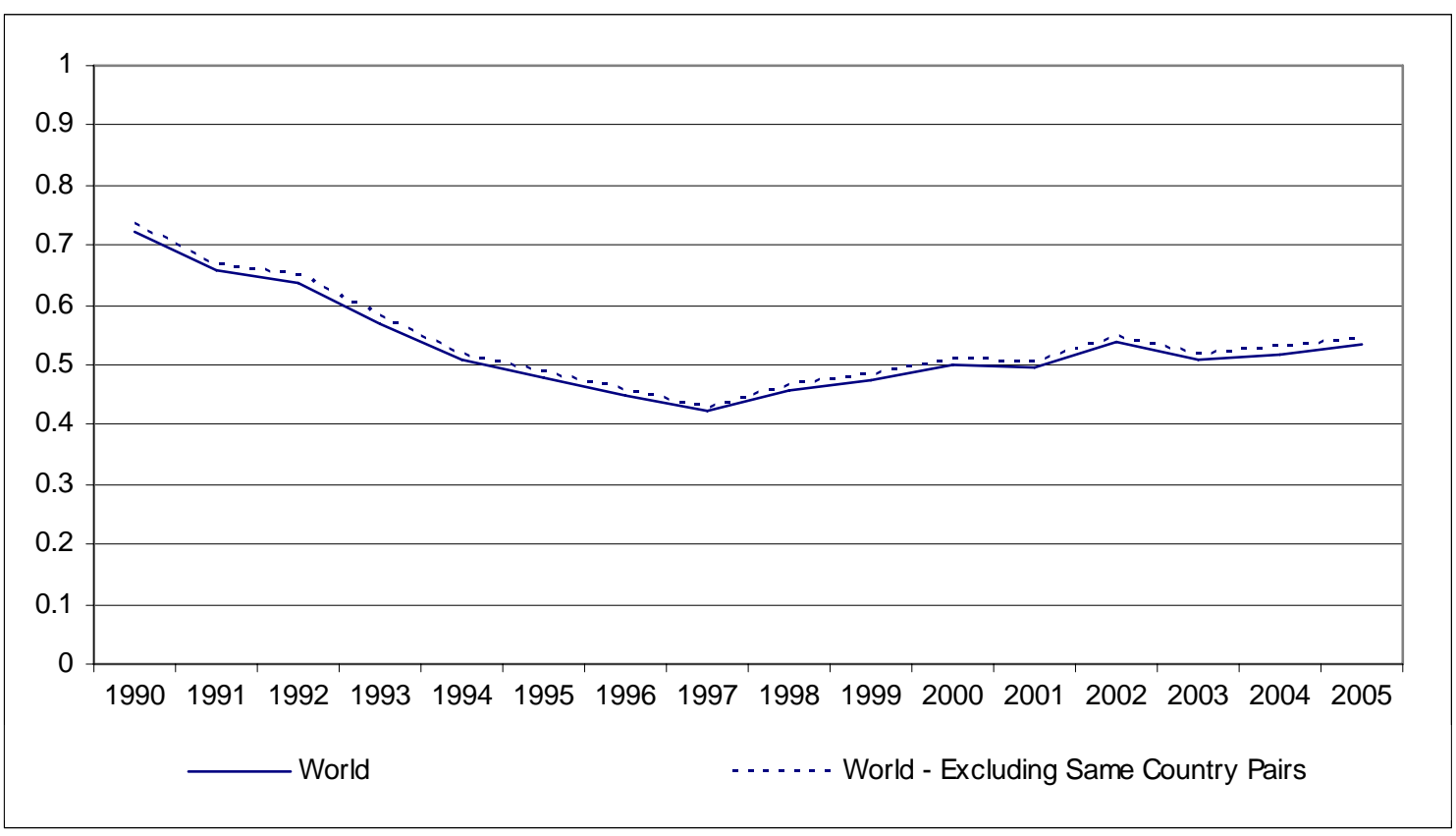

Note: "World-Excluding Same Country Pairs" omits city pairs where both cities are in the same country.

Fig. 2. Price Dispersion within and between Industrial and Developing Countries

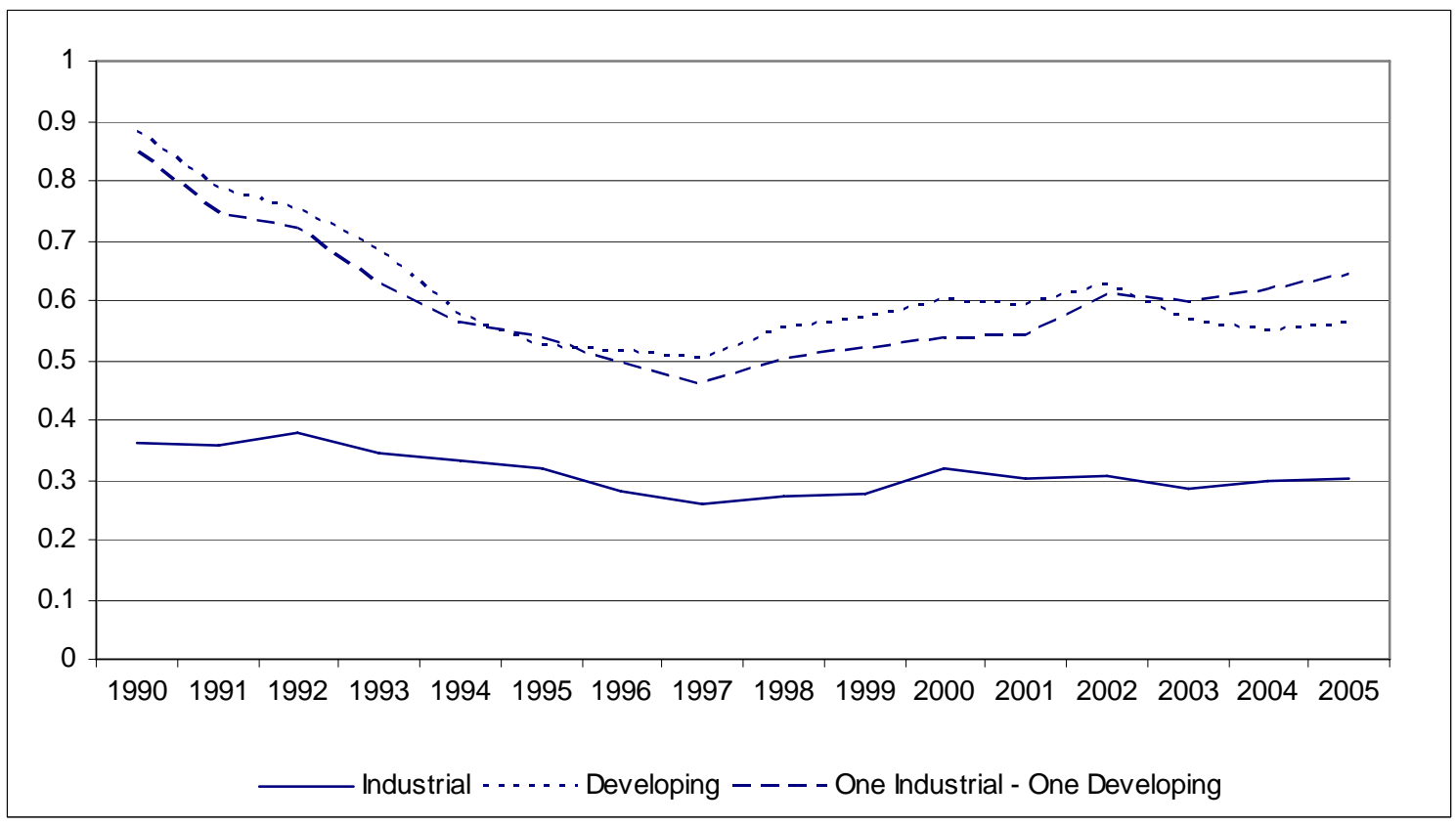

Note: "Industrial” denotes both cities in each pair are in industrial countries, "Developing” denotes both cities are in developing countries, and "One Industrial-One Developing” denotes only one city is in an industrial country, while the other is in a developing country. 
Fig. 3. Price Dispersion within Selected Regions

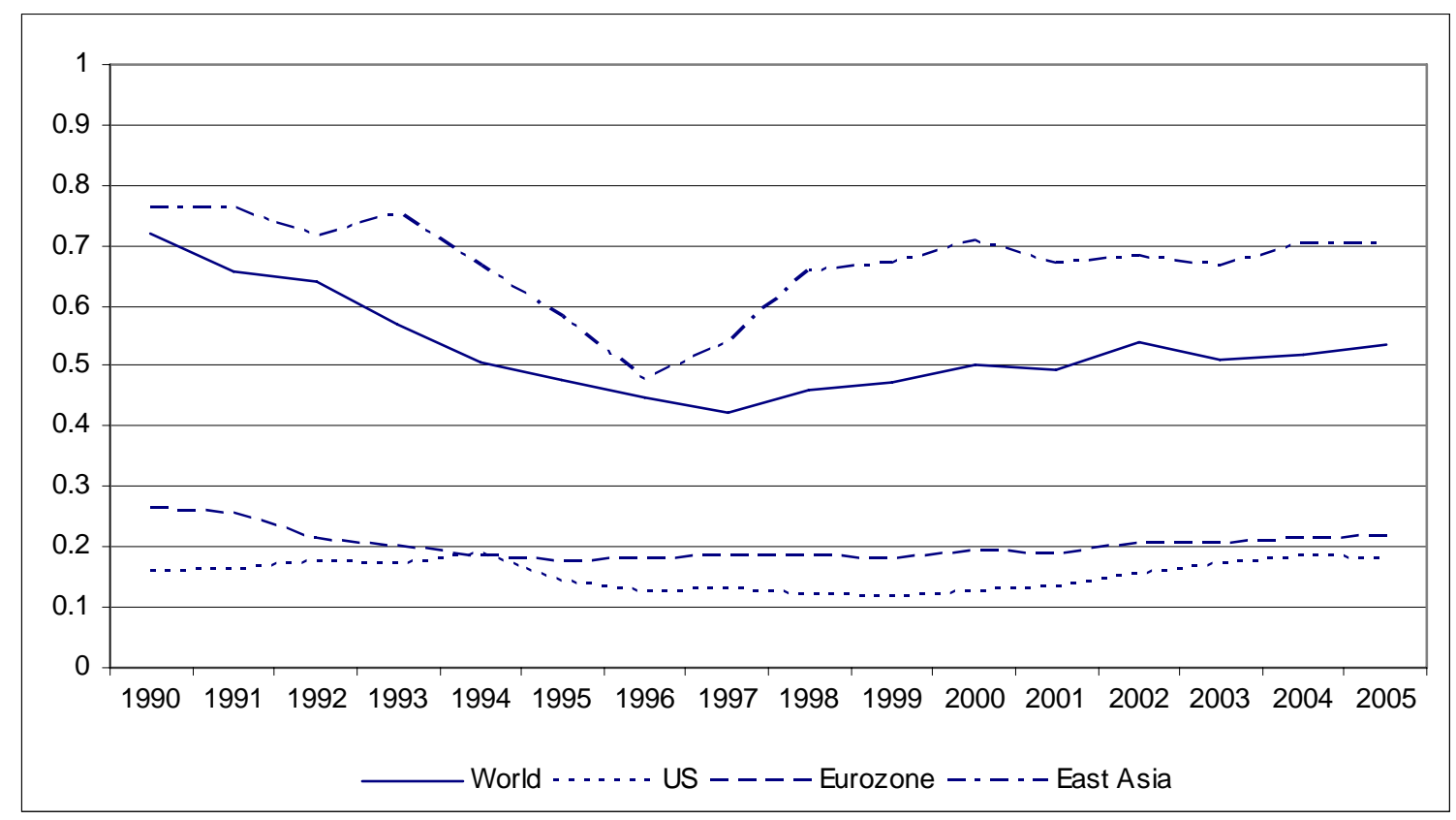

Fig. 4. Price Dispersion among Commodity Groups, Full World Sample

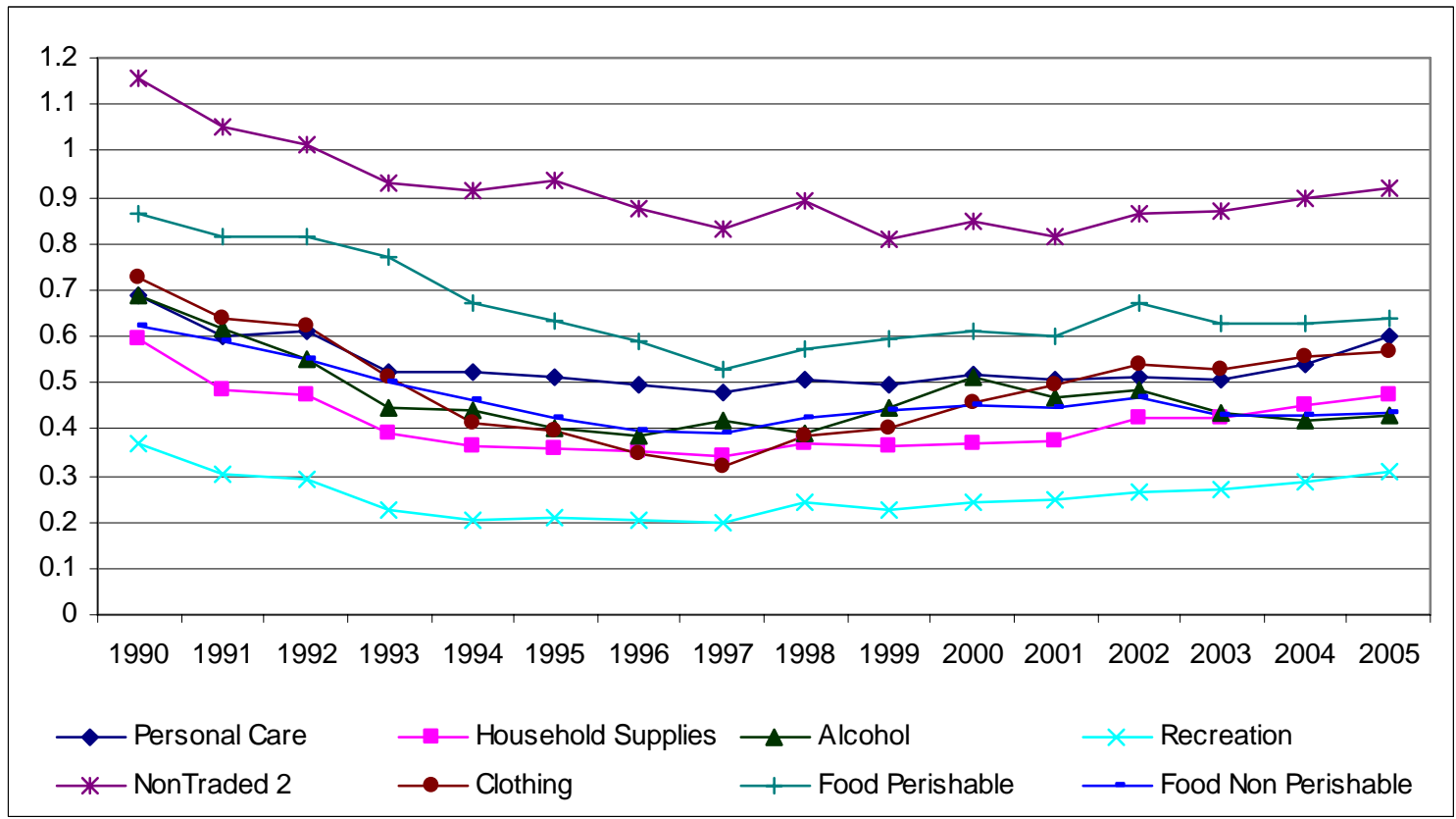

Note: See Appendix Table 1 for commodity group items. 
Figure 5a. Time-Varying Variables, Exchange Rate Volatility

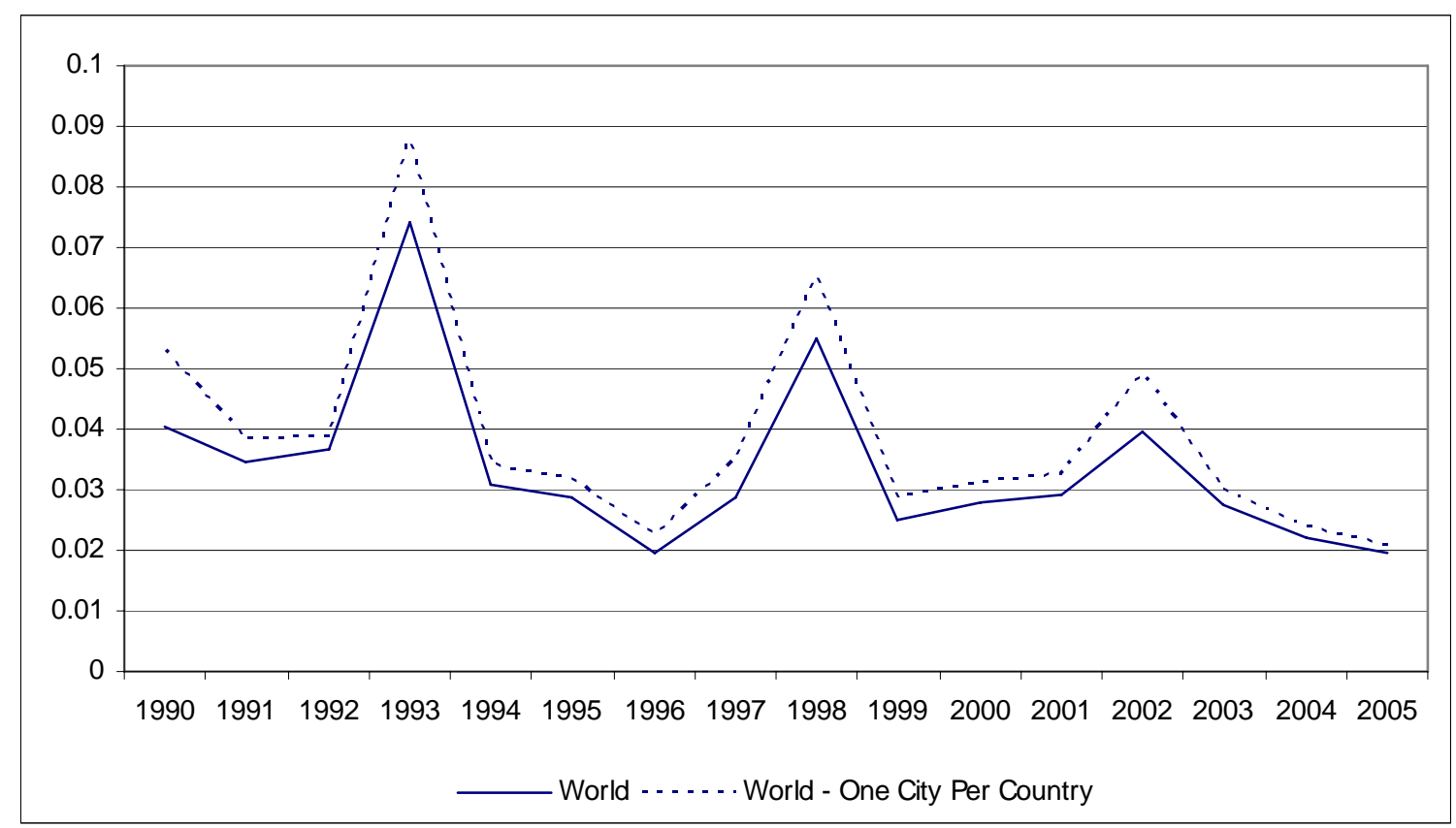

Note: “World-One City per Country” sample includes only pairs with one city per country.

Figure 5b. Time-varying Variables, Currency Crisis Frequency

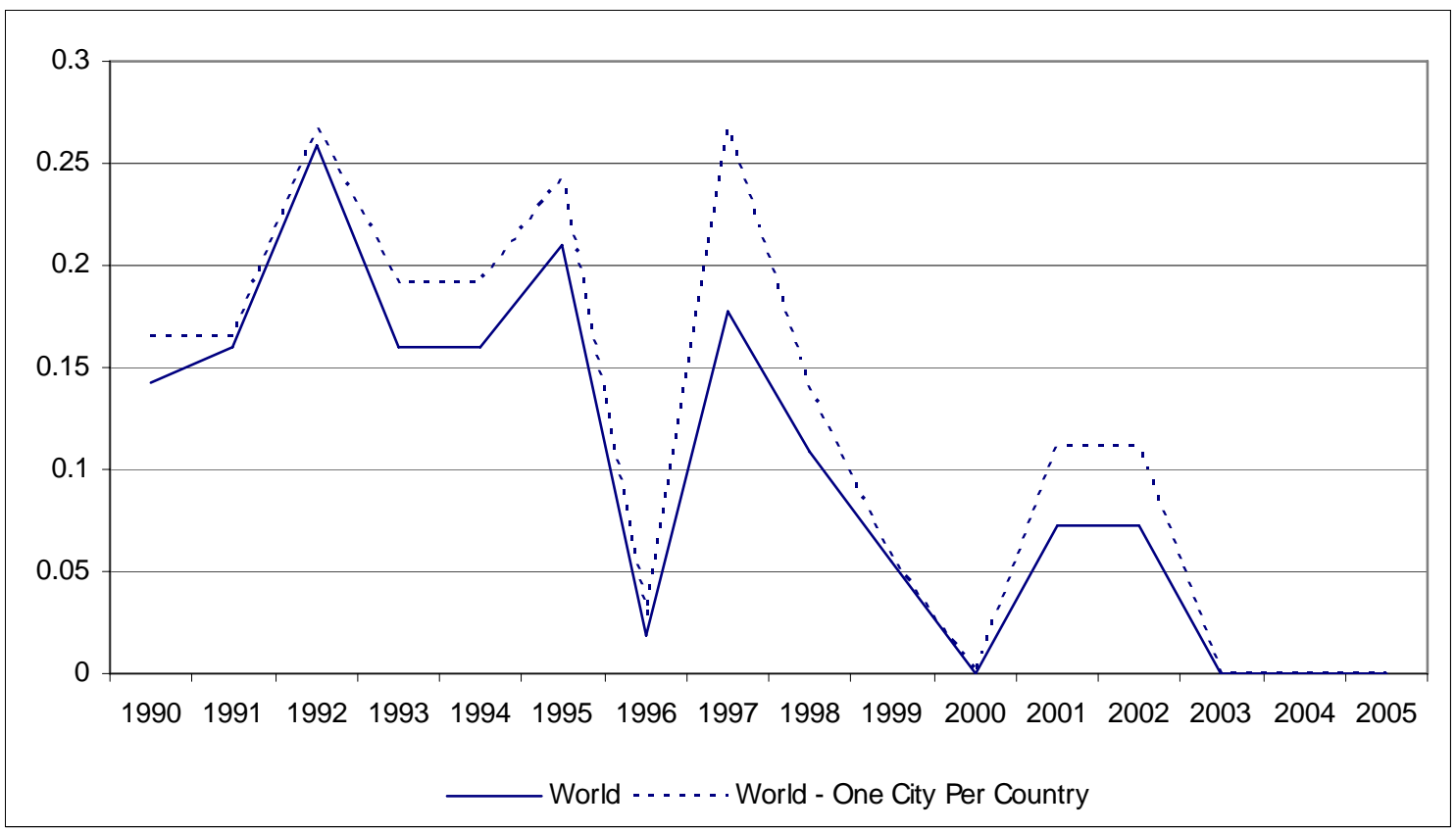

Note: “World-One City per Country” sample includes only pairs with one city per country. 
Fig. 6a. Time-varying Coefficients, Exchange Rate Volatility (with confidence bands)

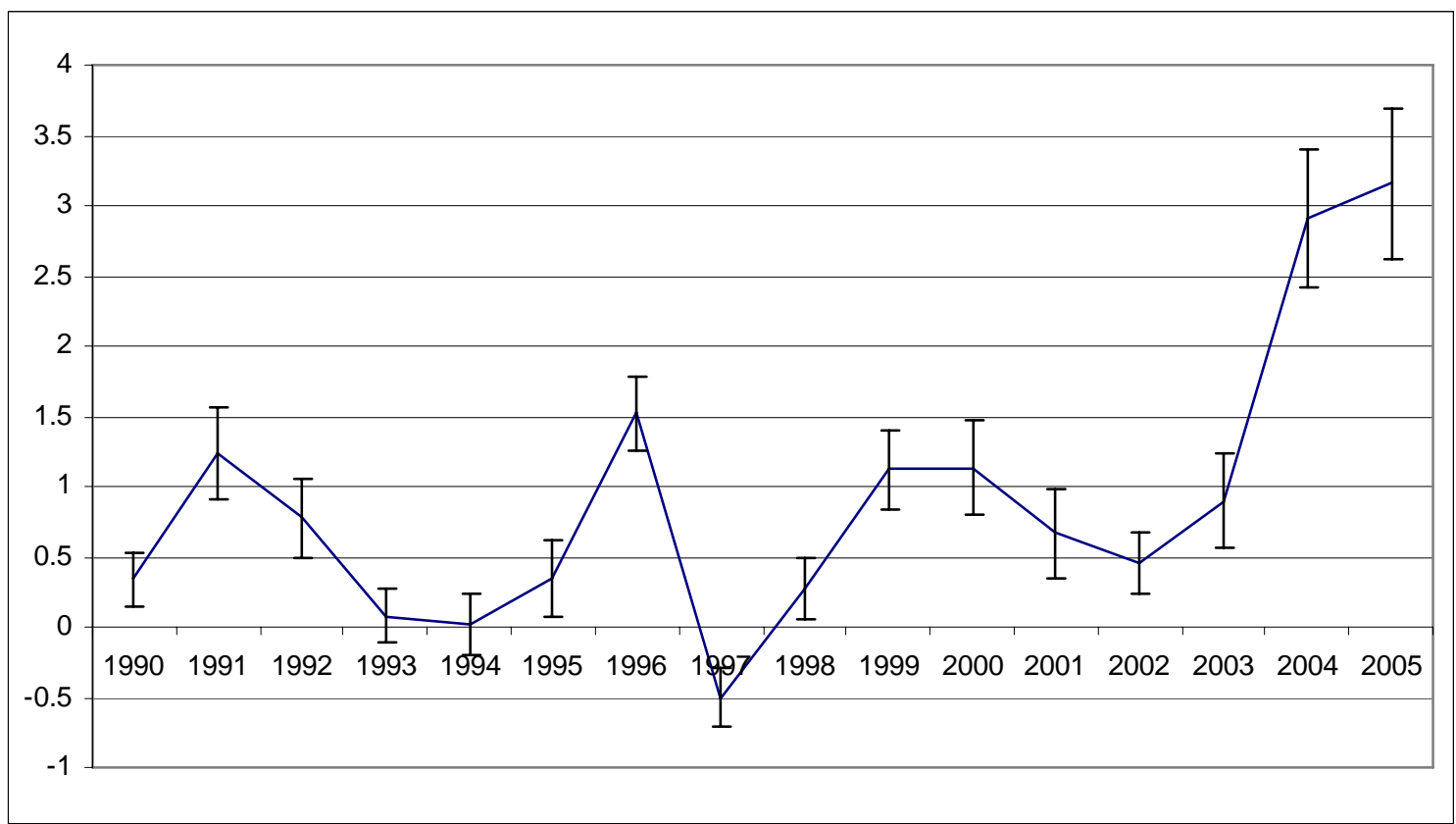

Note: Coefficients on exchange rate volatility from regression specification (3) in Table 1 augmented with interactive terms involving exchange rate volatility and year dummies (except 1990).

Fig. 6b. Time-varying Coefficients, Distance (with confidence bands)

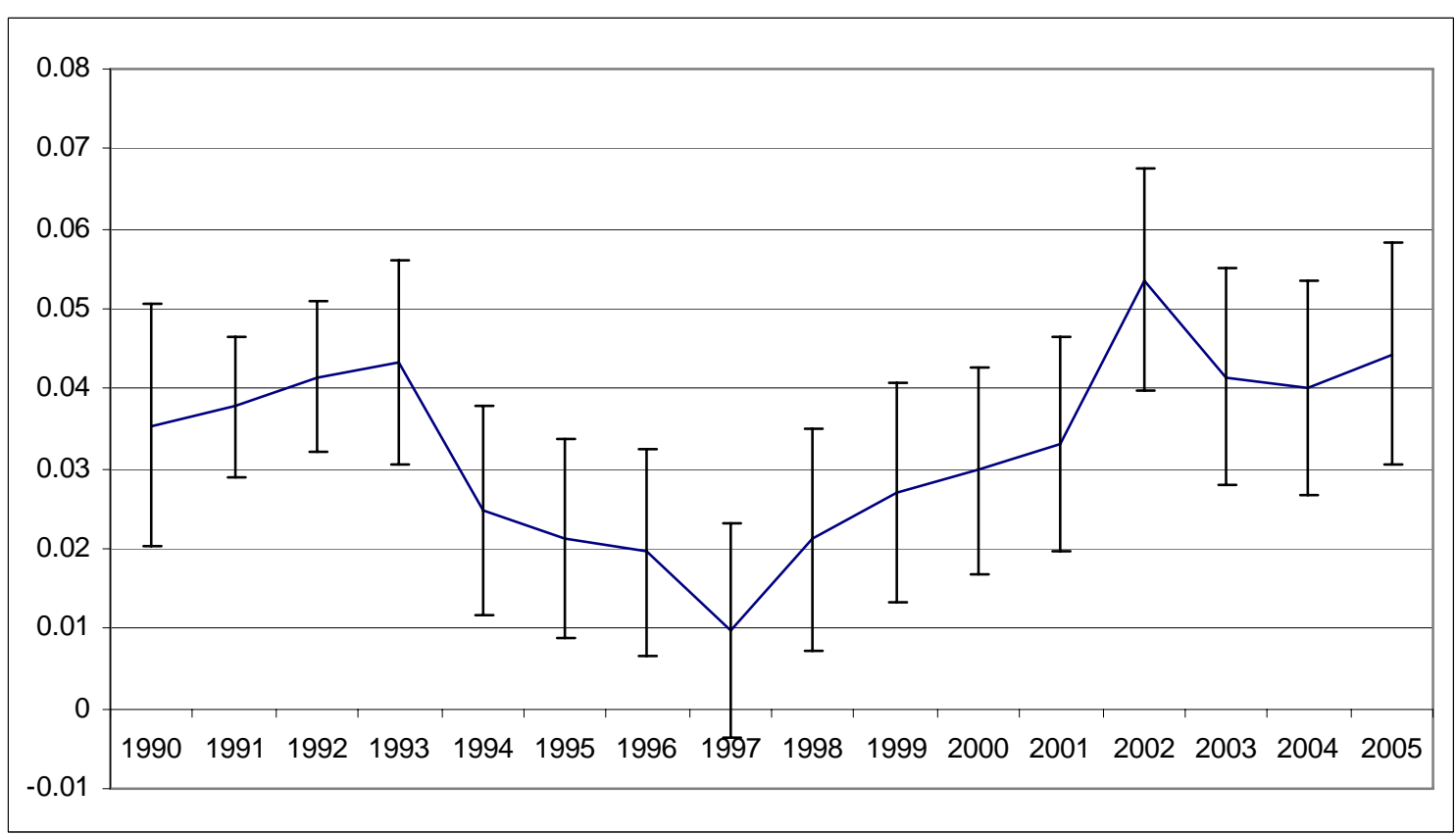

Note: Coefficients on log distance from regression specification (3) in Table 1 augmented with interactive terms involving log distance and year dummies (except 1990). 
Fig. 7. Real Oil Price and Transportation Costs

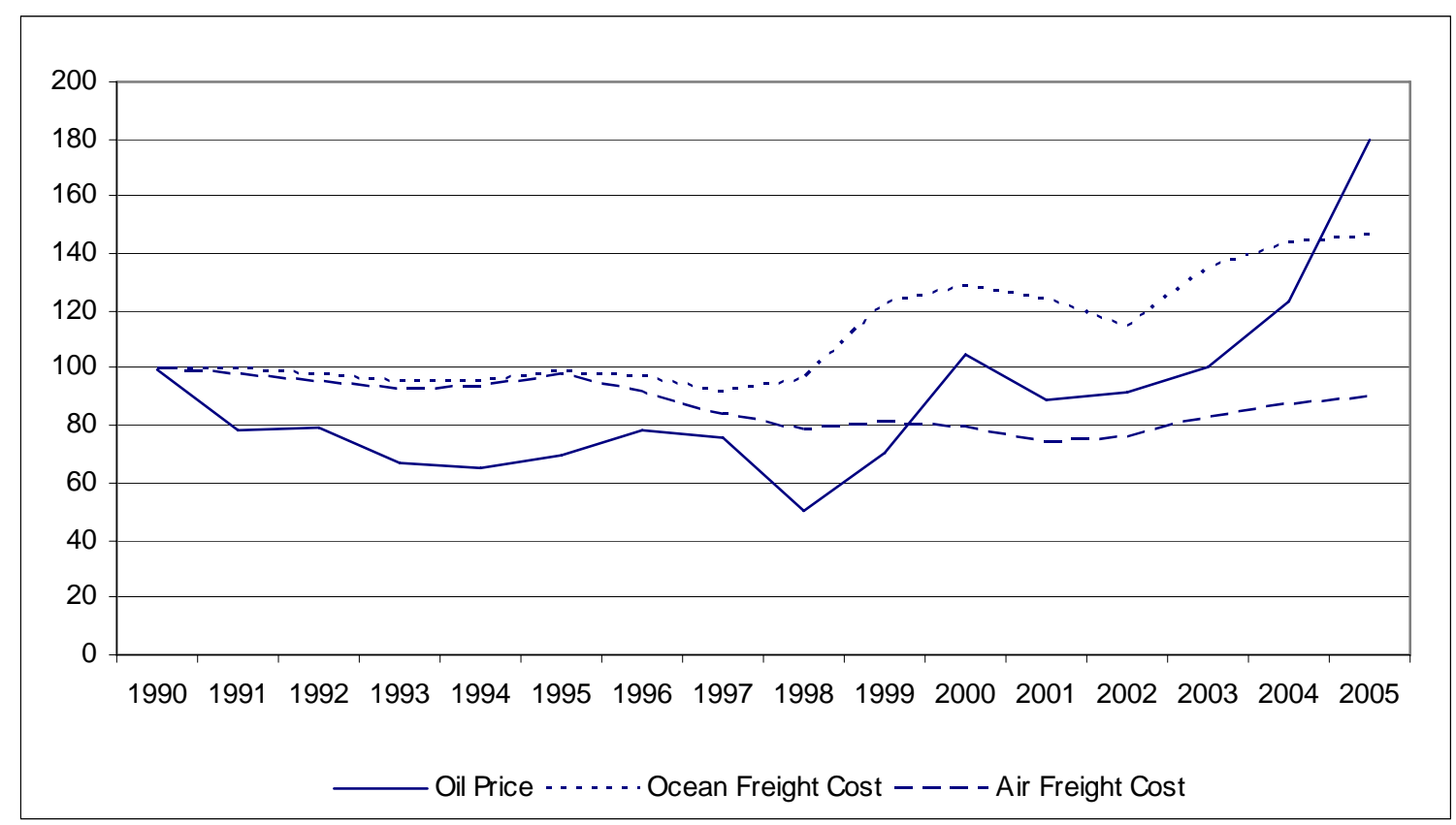

Note: All series are expressed relative to the U.S. CPI index and based to $1990=100$.

Fig. 8 Price Dispersion for World Sample, Unadjusted and Adjusted for Effects of Oil Prices

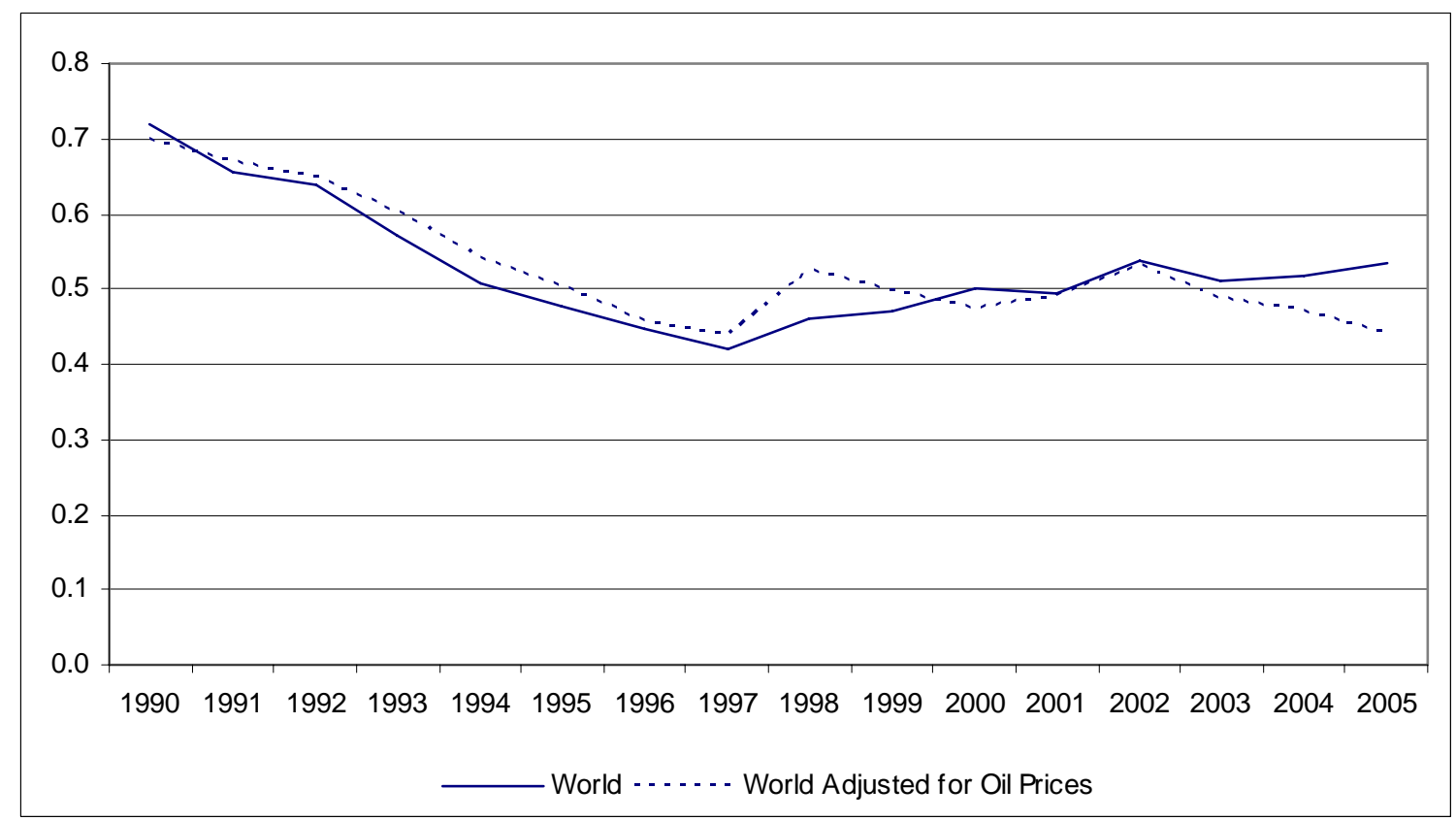

Note: World MSE Adjusted for Oil Prices constructed as MSE minus estimated coefficient of oil prices in Table 5, col. 1 (0.127) times the difference between the log of oil prices each year and their sample mean. 
Table A1. Traded Items in Sample, by Category

\begin{tabular}{|c|c|c|}
\hline $\begin{array}{l}\text { Food and non-alcoholic } \\
\text { beverages: perishable }\end{array}$ & $\begin{array}{l}\text { Food and non-alcoholic beverages: } \\
\text { Non-perishable }\end{array}$ & Alcoholic beverages \\
\hline White bread (1 kg) & White rice (1 kg) & Wine, common table (750 ml) \\
\hline Butter (500 g) & Olive oil (1 l) & Wine, superior quality (750 ml) \\
\hline Margarine (500 g) & Peanut or corn oil (1 l) & Wine, fine quality $(750 \mathrm{ml})$ \\
\hline Spaghetti (1 kg) & Peas, canned (250 g) & Beer, local brand (1 l) \\
\hline Flour, white (1 kg) & Tomatoes, canned (250 g) & Beer, top quality (330 ml) \\
\hline Sugar, white (1 kg) & Peaches, canned (500 g) & Scotch whisky, six yrs old (700 ml) \\
\hline Cheese, imported (500 g) & Sliced pineapples, can (500 g) & Gin, Gilbey’s or equivalent (700 ml) \\
\hline Cornflakes (375 g) & Chicken: frozen (1 kg) & Vermouth, Martini \& Rossi (1 l) \\
\hline Milk, pasteurised (1 l) & Frozen fish fingers ( $1 \mathrm{~kg})$ & Cognac, French VSOP (700 ml) \\
\hline Potatoes (2 kg) & Instant coffee (125 g) & Liqueur, Cointreau (700 ml) \\
\hline Onions (1 kg) & Ground coffee (500 g) & \\
\hline Tomatoes (1 kg) & Tea bags (25 bags) & Recreation \\
\hline Carrots (1 kg) & Сосоа (250 g) & Compact disc album \\
\hline Oranges (1 kg) & Drinking chocolate (500 g) & Television, colour $(66 \mathrm{~cm})$ \\
\hline Apples (1 kg) & Coca-Cola (1 l) & Kodak colour film (36 exposures) \\
\hline Lemons (1 kg) & Tonic water (200 ml) & Intl. weekly news magazine (Time) \\
\hline Bananas (1 kg) & Mineral water (1 l) & Internat. foreign daily newspaper \\
\hline Lettuce (one) & & Paperback novel (at bookstore) \\
\hline \multicolumn{3}{|l|}{ Eggs (12) } \\
\hline Beef: filet mignon (1 kg) & Clothing and footwear & Personal care \\
\hline Beef: steak, entrecote (1 kg) & Business suit, two piece, med. wt. & Aspirins (100 tablets) \\
\hline Beef: stewing, shoulder (1 kg) & Business shirt, white & Razor blades (five pieces) \\
\hline Beef: roast $(1 \mathrm{~kg})$ & Men’s shoes, business wear & Toothpaste with fluoride (120 g) \\
\hline Beef: ground or minced (1 kg) & Mens raincoat, Burberry type & Facial tissues (box of 100) \\
\hline Veal: chops (1 kg) & Socks, wool mixture & Hand lotion (125 ml) \\
\hline Veal: fillet (1 kg) & Dress, ready to wear, daytime & Lipstick (deluxe type) \\
\hline Veal: roast $(1 \mathrm{~kg})$ & Women’s shoes, town & \\
\hline Lamb: leg (1 kg) & Women's cardigan sweater & Household supplies \\
\hline Lamb: chops (1 kg) & Women’s raincoat, Burberry type & Toilet tissue (two rolls) \\
\hline Lamb: stewing (1 kg) & Tights, panty hose & Soap (100 g) \\
\hline Pork: chops (1 kg) & Child's jeans & Laundry detergent (3 l) \\
\hline Pork: loin (1 kg) & Child's shoes, dresswear & Dishwashing liquid (750 ml) \\
\hline Ham: whole (1 kg) & Child's shoes, sportswear & Insect-killer spray (330 g) \\
\hline Bacon (1 kg) & Girl’s dress & Light bulbs (two, 60 watts) \\
\hline Chicken: fresh (1 kg) & Boy’s jacket, smart & Frying pan (Teflon or equivalent) \\
\hline Fresh fish (1 kg) & Boy's dress trousers & Electric toaster (for two slices) \\
\hline Orange juice (1 l) & & Batteries (two, size D/LR20) \\
\hline
\end{tabular}




\section{Table A2. Non-traded items}

Laundry (one shirt)

Dry cleaning, man's suit

Dry cleaning, woman's dress

Dry cleaning, trousers

Man's haircut

Woman's cut \& blow dry

Telephone and line

Electricity

Gas Tune-up

Water

Business trip, daily cost

Hilton-type hotel, single room
Domestic cleaning help

Maid's monthly wages

Babysitter

Developing 36 colour pictures

Daily local newspaper

Three-course dinner

Seats at theatre or concert

Seats at cinema

Road tax or registration fee

Moderate hotel, single room

One drink at bar of hotel

Simple meal for one person
Regular unleaded petrol

Taxi: initial meter charge Taxi rate per additional kilometre Taxi: airport to city centre Two-course meal for two people Hire car 
Table A3. Cities Included in Sample

\begin{tabular}{|c|c|c|c|c|c|c|c|}
\hline 1 Abidjan & Cote d’Ivoire & 41 & Helsinki & Finland & 81 & Prague & Czech Republic \\
\hline 2 Abu Dhabi & United Arab Emirates & 42 & Hong Kong & Hong Kong & 82 & Quito & Ecuador \\
\hline 3 Adelaide & Australia & 43 & Honolulu & United States & 83 & Rio de Janeiro & Brazil \\
\hline 4 Alkhobar & Saudi Arabia & 44 & Houston & United States & 84 & Riyadh & Saudi Arabia \\
\hline 5 Amman & Jordan & 45 & Istanbul & Turkey & 85 & Rome & Italy \\
\hline 6 Amsterdam & Netherlands & 46 & Jakarta & Indonesia & 86 & San Francisco & United States \\
\hline 7 Asuncion & Paraguay & 47 & Jeddah & Saudi Arabia & 87 & San Jose & Costa Rica \\
\hline 8 Athens & Greece & 48 & Johannesburg & South Africa & 88 & Santiago & Chile \\
\hline 9 Atlanta & United States & 49 & Karachi & Pakistan & 89 & Sao Paulo & Brazil \\
\hline 10 Auckland & New Zealand & 50 & Kuala Lumpur & Malaysia & 90 & Seattle & United States \\
\hline 11 Bahrain & Bahrain & 51 & Kuwait & Kuwait & 91 & Seoul & Korea \\
\hline 12 Bangkok & Thailand & 52 & Lagos & Nigeria & 92 & Shanghai & China \\
\hline 13 Barcelona & Spain & 53 & Libreville & Gabon & 93 & Singapore & Singapore \\
\hline 14 Beijing & China & 54 & Lima & Peru & 94 & Stockholm & Sweden \\
\hline 15 Berlin & Germany & 55 & Lisbon & Portugal & 95 & St. Petersburg & Russia \\
\hline 16 Bogota & Colombia & 56 & London & United Kingdom & 96 & Sydney & Australia \\
\hline 17 Boston & United States & 57 & Los Angeles & United States & 97 & Taipei & Taiwan \\
\hline 18 Brisbane & Australia & 58 & Luxembourg & Luxembourg & 98 & Tehran & Iran \\
\hline 19 Brussels & Belgium & 59 & Lyon & France & 99 & Tel Aviv & Israel \\
\hline 20 Budapest & Hungary & 60 & Madrid & Spain & 100 & Tokyo & Japan \\
\hline 21 Buenos Aires & Argentina & 61 & Manila & Philippines & 101 & Toronto & Canada \\
\hline 22 Cairo & Egypt & 62 & Melbourne & Australia & 102 & Tunis & Tunisia \\
\hline 23 Calgary & Canada & 63 & Mexico City & Mexico & 103 & Vancouver & Canada \\
\hline 24 Caracas & Venezuela & 64 & Miami & United States & 104 & Vienna & Austria \\
\hline 25 Casablanca & Morocco & 65 & Milan & Italy & 105 & Warsaw & Poland \\
\hline 26 Chicago & United States & 66 & Montevideo & Uruguay & 106 & Washington DC & United States \\
\hline 27 Cleveland & United States & 67 & Montreal & Canada & 107 & Wellington & New Zealand \\
\hline 28 Colombo & Sri Lanka & 68 & Moscow & Russia & 108 & Zurich & Switzerland \\
\hline 29 Copenhagen & Denmark & 69 & Mumbai & India & & & \\
\hline 30 Dakar & Senegal & 70 & Munich & Germany & & & \\
\hline 31 Detroit & United States & 71 & Nairobi & Kenya & & & \\
\hline 32 Douala & Cameroon & 72 & New York & United States & & & \\
\hline 33 Dubai & United Arab Emirates & 73 & NewDelhi & India & & & \\
\hline 34 Dublin & Ireland & 74 & Osaka Kobe & Japan & & & \\
\hline 35 Dusseldorf & Germany & 75 & Oslo & Norway & & & \\
\hline 36 Frankfurt & Germany & 76 & Panama City & Panama & & & \\
\hline 37 Geneva & Switzerland & 77 & Paris & France & & & \\
\hline 38 Guangzhou & China & 78 & Perth & Australia & & & \\
\hline 39 Guatemala City & Guatemala & 79 & Pittsburgh & United States & & & \\
\hline 40 Hamburg & Germany & 80 & Port Moresby & Papua New Guinea & & & \\
\hline
\end{tabular}

Note: Italicized countries contain more than 1 city in the sample. 